\title{
32. PALYNOLOGICAL STUDY OF UPPER JURASSIC AND LOWER CRETACEOUS SEDIMENTS, SITE 511, DEEP SEA DRILLING PROJECT LEG 71 (FALKLAND PLATEAU) ${ }^{1}$
}

\author{
Ida Z. Kotova, Geological Institute of the U.S.S.R. Academy of Sciences, Moscow, U.S.S.R.
}

\begin{abstract}
Samples from Upper Jurassic and Lower Cretaceous sediments at Site 511 were analyzed for palynomorphs. Three palynological assemblages were identified: Upper Jurassic (presumably Tithonian), Neocomian-Aptian, and lower Albian. These were correlated to synchronous assemblages in Argentina, South Africa, and Australia and were compared with Jurassic palynoassemblages from Hole 330, Leg 36.
\end{abstract}

\section{INTRODUCTION}

At Site 511, on the Falkland Plateau (western part of the Maurice Ewing Bank), Upper Jurassic and Lower Cretaceous sediments were penetrated by Hole 511, drilled to a depth of 632 meters some $10 \mathrm{~km}$ from Site 330 (Leg 36). Within the Jurassic-Lower Cretaceous interval, two lithological units (Units 5 and Unit 6) were identified. The upper unit (Unit 5) is composed of calcareous claystones. Their oxidation state did not favor the preservation of organic matter: the sediments contain no spores, pollen, dinoflagellate cysts, or plant detritus.

The lower unit (Unit 6) is composed of black shales containing $1.7-4.1 \%$ organic carbon. In this unit, only 47 of all samples taken contained spores, pollen, dinoflagellate cysts, and great amounts of plant detritus.

The samples were treated with hydrochloric acid, potassium sodium hydroxide, hydrofluoric acid, and cadmium liquid.

The results of the palynological analysis are summarized in Table 1, which shows the percentage of spores and pollen. Figure 1 shows the stratigraphic distribution of the most characteristic species and genera. Photographs in Plates 1-15 were made with a Biolam microscope and a MNF-12 microphotographic device.

\section{DISTRIBUTION OF SPORES AND POLLEN IN UPPER JURASSIC AND LOWER CRETACEOUS SEDIMENTS AT SITE 511; AGE OF PALYNOASSEMBLAGES}

Organic remains of plant origin in the interval between 498 and 632 meters (Unit 6, Cores 70-56) consisted of plant detritus, spores, pollen, and dinoflagellate cysts. The last were not examined in this study. Plant detritus in Cores 70-59 is in the form of amorphous sapropelic material and fragments of cuticles and tracheids belonging to terrestrial plants. The distribution of pollen and spores in this interval is variable. They are abundant in Cores 70-68 and 63-60 but not numerous in Cores 6764 and 59. In some samples from the uppermost parts of

\footnotetext{
${ }^{1}$ Ludwig, W. J., Krasheninnikov, V. A., et al., Init. Repts. DSDP, 71: Washington (U.S. Govt. Printing Office)
}

this interval (Cores 63, 61, 59), amorphous detritus is coagulated into rounded yellow brown aggregates with an admixture of pyrite. Traces of pyrite are seen on the surfaces of spores and pollen.

The available sapropelic material enables us to assume that black shales in this interval were formed under anaerobic conditions. The uneven distribution of pollen and spores suggests an alternation of anaerobic conditions with slightly oxidizing environments. However, low abundances of spores can be due to unfavorable climatic conditions for ferns on the nearby land. Amorphous sapropelic material disappears at the beginning of Core 58.

In Sample 511-58-3, 53-55 cm, the plant detritus consists of large, bright orange, cuticular remains. The content and diversity of fern spores sharply increase. From Sample 511-58-2, 142-144 cm to Sample 511-56-4, 142$144 \mathrm{~cm}$ the plant detritus contains fragments of middlesized cuticles and tracheids, brown to black in color, with an admixture of crushed micrinitic material. Disappearance of sapropelic material may denote the beginning of oxidizing processes, and the admixture of micrinitic material may suggest a certain remoteness from a source area. Diverse and numerous fern spores lead us to assume that climatic conditions for the existence of ferns were favorable on the nearby land.

The palynological analysis allowed us to distinguish three assemblages within the interval from 495 to 632 meters.

\section{Assemblage I}

Assemblage I was identified in the interval from 632 to 555 meters (Cores 70-63). Of 31 samples analyzed, 18 contained spores and pollen.

The assemblage abounds in gymnosperm pollen in which Classopollis predominates $(45.5-78 \%)$ and Vitreisporites pallidus $(7.5-38 \%)$ is abundant. Bisaccate and trisaccate conifer pollen and pollen of the genus Callialasporites ( $C$. dampieri, $C$. trilobatus, $C$. turbatus, $C$. segmentatus) are always present. Less frequent is monosaccate conifer pollen (Monosaccites sp. 1), Sulcosaccispora sp., and Araucariacites australis. Spores are not numerous $(2.0-8 \%)$ and are represented mostly by Antulsporites saevus, A. varigranulatus, Converrucosi- 
Table 1. Percentage chart of spores and pollen in Upper Jurassic and Lower Cretaceous sediments, Site 511.

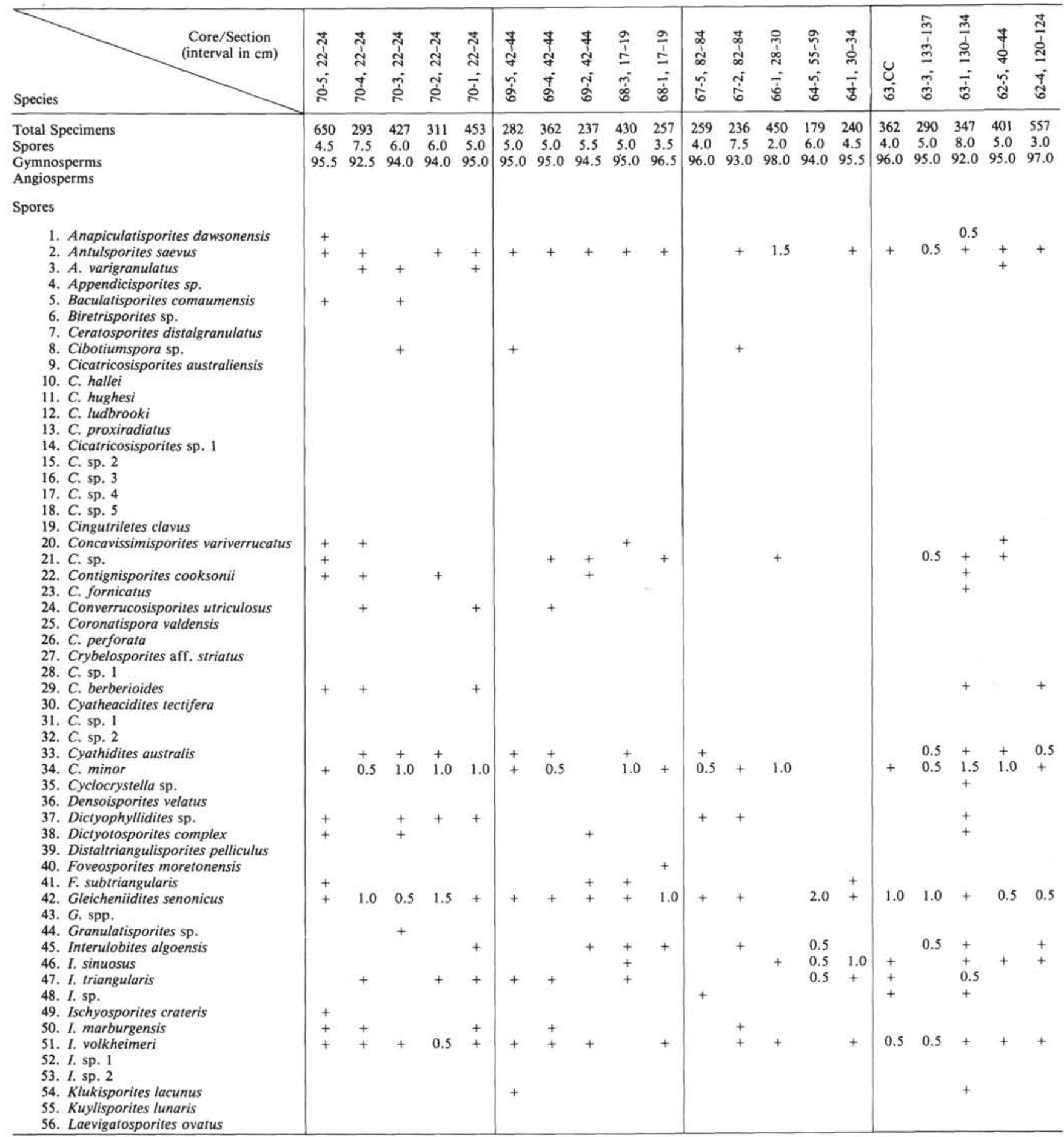

Note: + indicates content $<0.5 \%$.

sporites utriculosus, Cyathidites australis, C. minor, Dictyophyllidites sp., Gleicheniidites senonicus, Interulobites algoensis, I. triangularis, I. sinuosus, Ischyosporites volkheimeri, I. marburgensis, Leptolepidites verrucatus, Matonisporites crassiangulatus, Nevesisporites sp., and Staplinisporites caminus. Less frequently recognized were Anapiculatisporites dawsonensis, Concavissimisporites variverrucatus, Contignisporites cook- sonii, Dictyotosporites complex, Foveosporites subtriangularis, Ischyosporites crateris, Marattisporites scabratus, and others (Plate 1).

The age of Assemblage I is Upper Jurassic. No forms that were observed are peculiar to Lower Cretaceous sediments. The assemblage contains species and genera that are always found in Jurassic sediments of Australia, Argentina, and South Africa: trisaccate conifer pol- 
Table 1. (Continued).

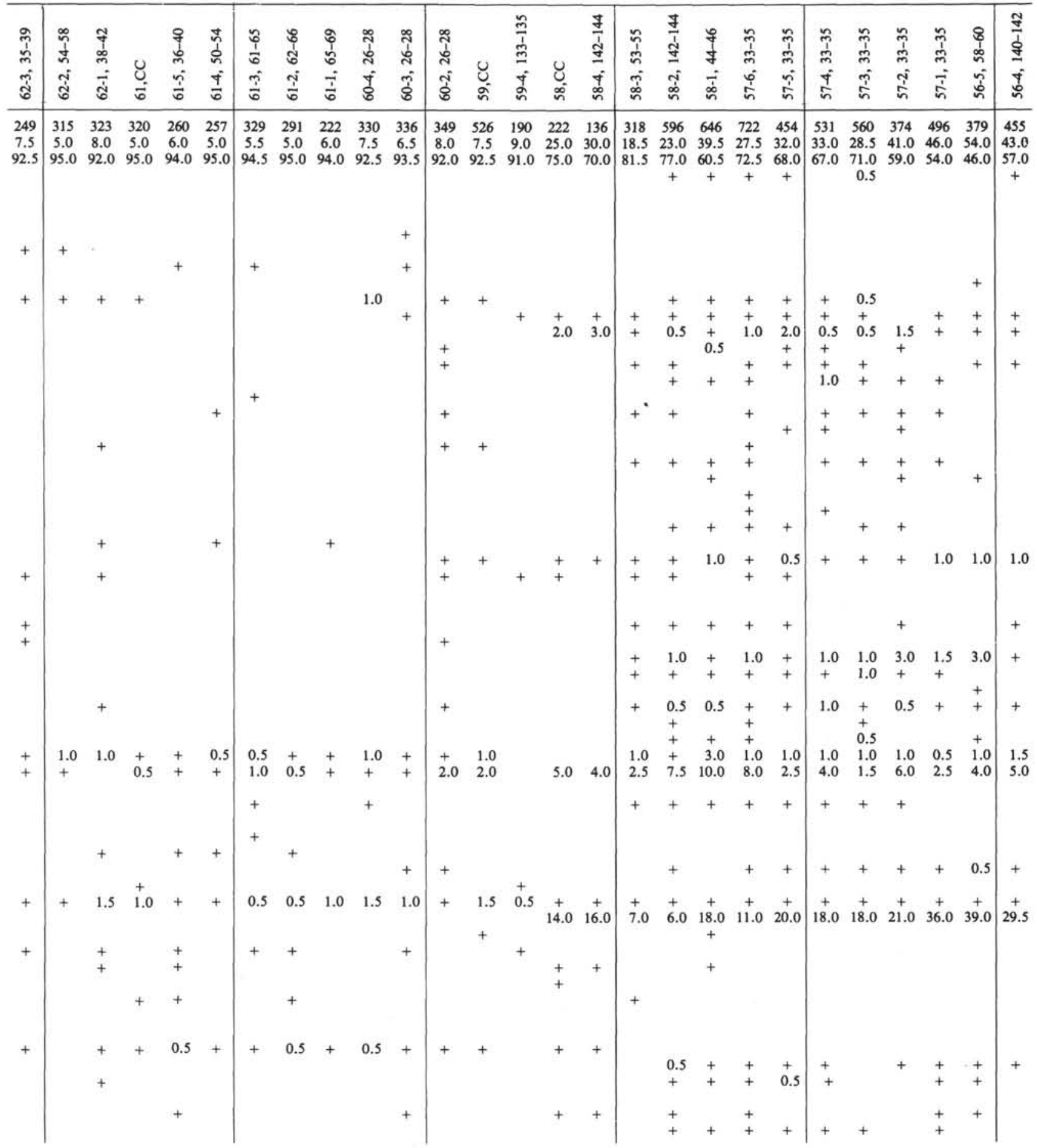

len, Callialasporites spp., Contignisporites cooksonii, Antulsporites saevus, Ischyosporites spp., Matonisporites crassiangulatus, Dictyotosporites complex. Contignisporites cooksonii appears in Australia and Argentina in Upper Jurassic sediments (Volkheimer and Quattrocchio, 1975; Filatoff, 1975). Most similar in composition to the Jurassic assemblage of Site 511 is an assemblage studied from sediments of the Vaca Muerta Formation
(Neuquén Province, Argentina), the lower-middle Tithonian age of which has been established by means of pelecypods, ammonites, fish, and remains of ichthyosaurs (Volkheimer and Quattrocchio, 1975; Malumián and Báez, 1976). The palynoassemblage of this formation is characterized by abundance of Classopollis (up to $64.6 \%$ ), a small amount of Araucariacites australis, trisaccate conifer pollen, the presence of the spores Con- 
Table 1. (Continued).

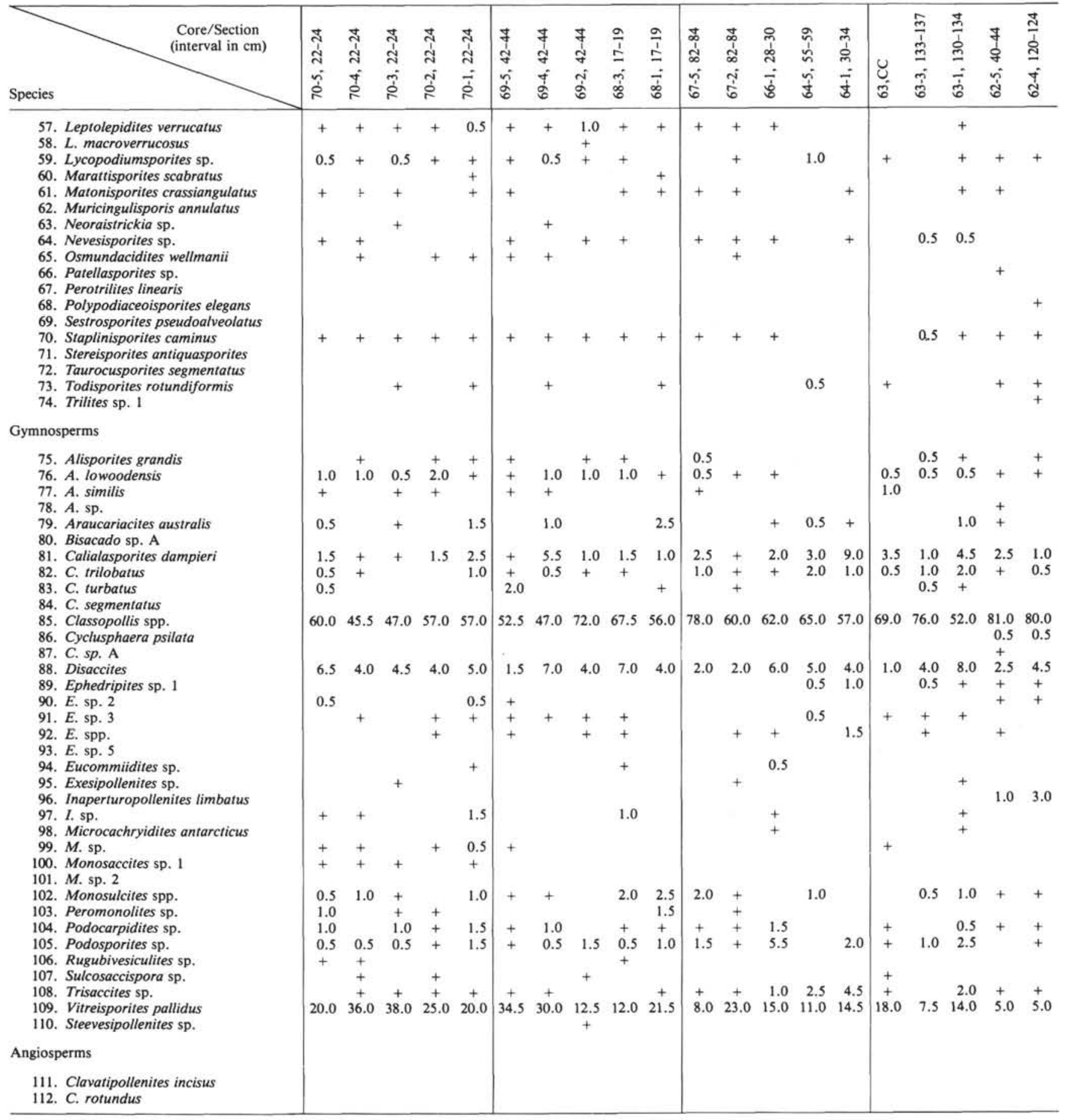

Note: + indicates content less than $0.5 \%$.

tignisporites cooksonii, Interulobites spp., Leptolepidites spp., and some other species. The only difference in the Vaca Muerta Formation is the presence there of two specimens of Cicatricosisporites (identified as Appendicisporites) in one interlayer. In the samples of Site 511, these spores appear in the Lower Cretaceous assemblage. The Oxfordian-Kimmeridgian assemblages in Argentina are not known. In the Callovian of Argentina (Neuquén Province), a small percentage of Classopollis (up to $10 \%$ ) was recorded; spores of the genus Interulobites are absent (Volkheimer, 1971). Upper Jurassic assemblages of Australia differ from those of Site 511 in their small percentage of Classopollis (5-20\%) and large amount of Araucariacites australis pollen (35-40\%) and in the presence of Murospora florida spores.

Assemblages of similar composition were distinguished from the Kirkwood Formation (except for the upper part) of the Uitenhage Group in South Africa. 
Table 1. (Continued).

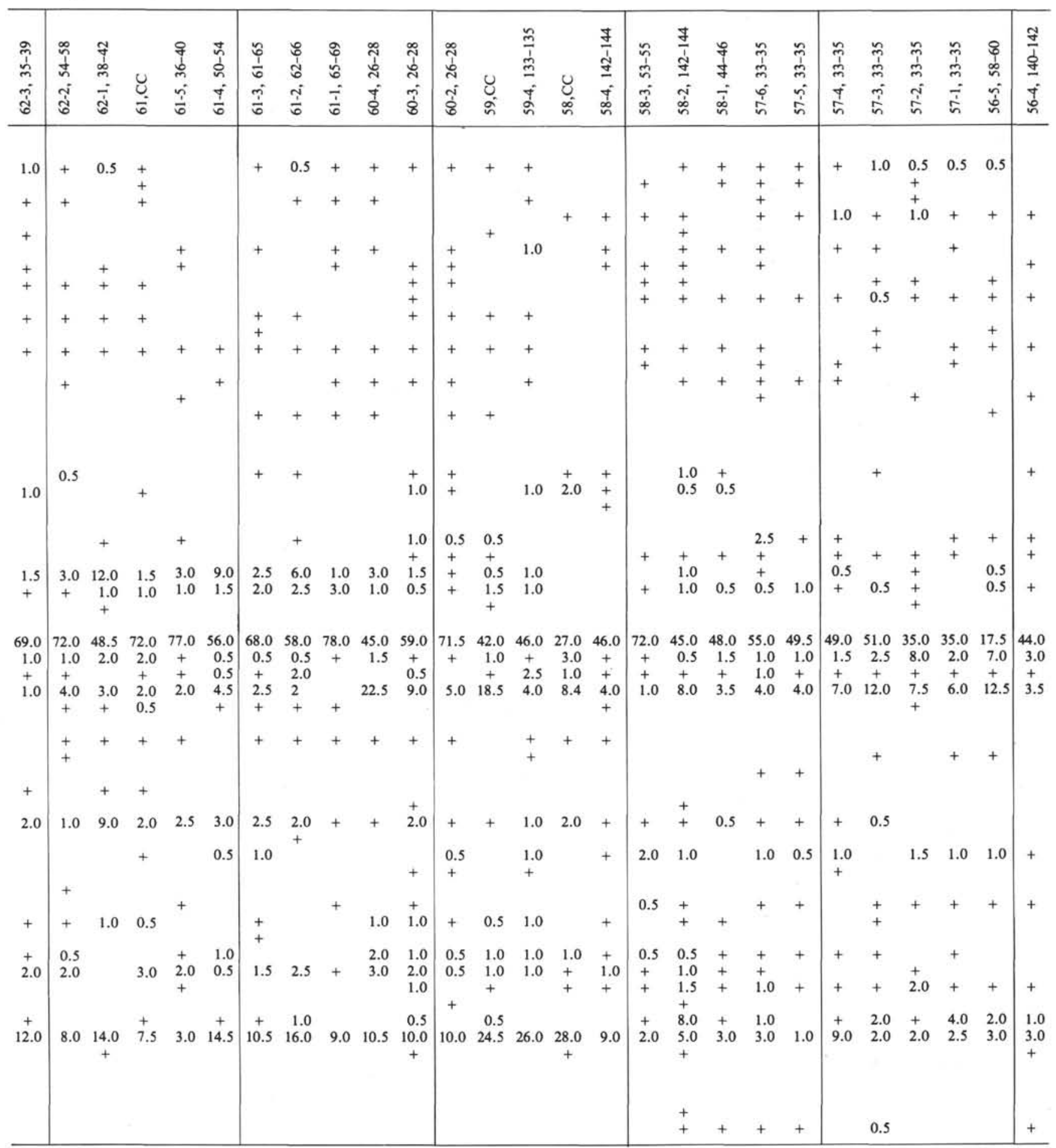

The Kirkwood Formation is composed of continental deposits, Upper Jurassic-Lower Cretaceous in age, and overlain by the Sundays River Formation, which contains benthic foraminifers, ostracodes, and mollusks that place its age within the Valanginian-Hauterivian (Scott, 1976). The palynological assemblage of the Kirkwood Formation and the Upper Jurassic assemblage of Site 511 are both characterized by a considerable content of Classopollis pollen and by the presence of spores of the genus Interulobites.

\section{Assemblage II}

Assemblage II was identified in the interval from 555 to 518 meters (Cores 62-59). Of 20 samples analyzed, 16 contained spores and pollen.

The assemblage abounds in gymnosperm pollens within which, as in the previous assemblage, Classopollis $(42-81 \%)$ and Vitreisporites pallidus (3-26\%) are predominant. An important difference from the previous assemblage is the appearance of Inaperturopollenites 


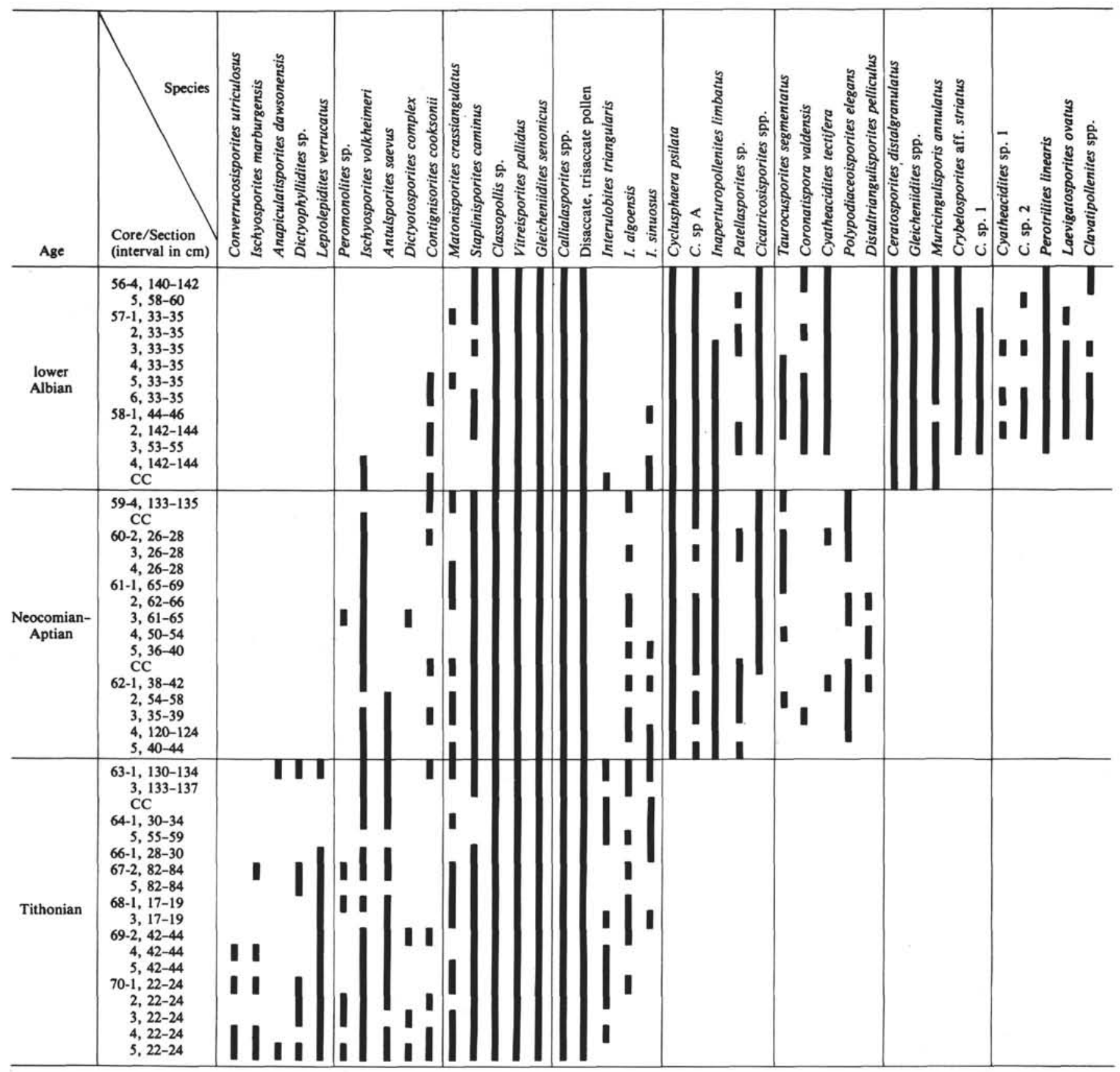

Figure 1. Pollen diagram of some species in Upper Jurassic and Lower Cretaceous sediments, Hole 511.

limbatus and Cyclusphaera psilata. Both forms are representative of the Lower Cretaceous only. I. limbatus is found in the Lower Cretaceous in Australia, South America, and Argentina; $C$. psilata has not been known in Australia, but is characteristic of Lower Cretaceous assemblages of South Africa and Argentina. Again, as in Assemblage I, spores are not numerous (3-9\%) and their composition is generally similar to that assemblage. A number of species, however, disappear. These are Anapiculatisporites dawsonensis, Dictyophyllidites sp., Ischyosporites marburgensis, Klukisporites lacunus, and Leptolepidites verrucatus. Rare spores of Cicatricosisporites, Cyatheacidites tectifera, Trilites sp. 1,
Polypodiaceoisporites elegans, Taurocusporites segmentatus, and Distaltriangulisporites pelliculus appear. Beginning from Sample 511-60-3, 26-28 cm, pollen of Bisacado sp. A appears.

It is impossible to date precisely the age of Assemblage II, as there are no detailed descriptions of sporepollen assemblages of some of the Lower Cretaceous stages in the Southern Hemisphere. We can, however, determine an approximate age. First, $P$. elegans and $C$. tectifera, which appear in this interval, have been described from Barremian-Aptian continental deposits of the Baqueró Formation, Santa Cruz Province, Argentina (Archangelsky and Gamerro, 1965, 1966, 1967). D. 
pelliculus was described from Lower Cretaceous sediments of the Sundays River Formation in South Africa (Scott, 1976) and its age was tentatively determined as Valanginian-Hauterivian by means of ostracodes, benthic foraminifers, and mollusks. Many species observed in Assemblage II of Site 511 also appear in sediments from the upper part of the Kirkwood and Sundays River formations. There are Interulobites algoensis, I. sinuosus, rare Cicatricosisporites, Cyclusphaera sp. A (described as Inaperturopollenites sp. VI), and Inaperturopollenites limbatus (described as Inaperturopollenites sp. 1). Assemblages similar in composition were distinguished in the Ortiz and Agrio formations in Neuquen Province, Argentina (Volkheimer and Sepúlveda, 1976; Volkheimer et al., 1977). The Agrio Formation is composed of marine sediments with corals, ammonites, pelecypods, and gastropods that allow one to determine its age as Hauterivian-early Barremian (Volkheimer and Sepúlveda, 1976; Malumián and Báez, 1976). The Ortiz Formation is of continental origin and can be correlated by spores and pollens with the Agrio Formation. Assemblages from the Ortiz and Agrio formations also abound in Classopollis pollen; Cyclusphaera psilata, Inaperturopollenites limbatus, and Bisacado sp. A are present as well. Spores are not numerous. Taurocusporites $\mathrm{cf}$. segmentatus and Trilites $\mathrm{sp} .1$ (determined as Leptolepidites $\mathrm{sp}$.) were recognized.

At Site 327, drilled during Leg 36 on the Falkland Plateau (Hedlund and Beju, 1977), two spore-pollen assemblages were distinguished; the lower one is Neocomian-Aptian in age (interval 396-463 m) and is similar to Assemblage II of Site 511 in its abundance of Classopollis, presence of Cyclusphaera psilata (determined as Coptospora sp.), and rare Cicatricosisporites. A similar assemblage was identified in the Cape Basin near the coasts of South Africa at Site 361 (Cores 27-49). Some researchers have estimated its age as Aptian-Albian (McLachlan and Pieterse, 1978), others as Aptian (Davey, 1978). Predominant in this assemblage also is Classopollis pollen; I. limbatus, Cyclusphaera psilata (identified as I. sp. VII), and rare Cyatheacidites tectifera, Cicatricosisporites, and Gleicheniidites are present as well. This assemblage differs from that of Site 511 in the presence of very rare specimens on monocolpate angiosperm pollen (Liliacidites, Clavatipollenites).

So Assemblage II of Site 511 is similar to a spore-pollen assemblage from the Agrio and Ortiz formations of Hauterivian-Barremian age; to one from the Baqueró Formation of Barremian-Aptian age; to one from Site 327 of Neocomian-Aptian age; to one from Site 361 of Aptian age (Cores 27-49) and to one from the Sundays River Formation of Valanginian-Hauterivian age.

The age of Assemblage II could have been determined as pre-Barremian, since we found no monocolpate pollen of Clavatipollenites angiosperms, which appear in many regions of the world in the Barremian. Yet some species (Polypodiaceoisporites elegans and Cyatheacidites tectifera) described from Barremian-Aptian continental deposits of the Baqueró Formation are present in the assemblage, although their vertical distribution is not known. Therefore, the age of the deposits, including
Assemblage II, can be established, for the time being, within a wider range, for instance, Neocomian-Aptian.

\section{Assemblage III}

Assemblage III was distinguished within the interval 518-495 meters (Cores 56-58). All of the 13 samples analyzed except the two lower ones (Samples 511-58,CC and 511-58-4, 142-144 cm) contain great amounts of spores and pollen. The spore/pollen ratio varies. In general, the amount of spores becomes greater (18.5$54.0 \%$ ), mainly through an increase in specimens of the spores Gleicheniidites (6-39\%) and Cyathidites minor (1.5-10\%); spores of Cicatricosisporites become more diverse. Some new species of spores appear; Biretisporites sp., Ceratosporites distalgranulatus, Cingutriletes clavus, Crybelosporites aff. striatus, Crybelosporites sp. 1, Densoisporites velatus, Laevigatosporites ovatus, Muricingulisporis annulatus, Perotrilites linearis, and Cyatheacidites tectifera are constant. Pollen of the genus Classopollis prevails as before, through its percentage is less than in the previous assemblage (17.5-55\%). Only in Sample 511-58-3, 53-55 cm does it amount to as much as $72 \%$. Cyclusphaera psilata and bisaccate, trisaccate, and monosaccate conifer pollens are present. The monosaccate pollens are represented by small forms (Monosaccites sp. 2). The amount of Vitreisporites pallidus pollen diminishes. Only in the lowermost sample (511-58,CC) does it amount to $28 \%$; in the remaining samples it ranges between 1 and $9 \%$. In this assemblage, monocolpate angiosperm pollen appears, represented by the genus Clavatipollenites.

Assemblage III is determined to be Albian. Some of the species just listed were described or mentioned in the assemblage of the Barremian-Aptian Baqueró Formation, (Archangelsky and Gamerro, 1965, 1966, 1967): Cyatheacidites tectifera, Muricingulisporis annulatus, Monosulcites sp. 2 (as a monosaccate specimen), Clavatipollenites rotundus (as C. hughesii), and Cyclusphaera psilata (as Inaperturopollenites sp.). However, such characteristic species of Assemblage III as Ceratosporis distalgranulatus, Crybelosporites aff. striatus, $C$. sp. 1, and large forms of Gleicheniidites, Perotrilites linearis, and Laevigatosporites ovatus were not observed in the Baqueró Formation. Ceratosporites distalgranulatus was described from Aptian-Albian deposits in England (Kemp, 1970); Crybelosporites aff. striatus is similar to $C$. striatus, a peculiar lower Albian species from Australia (Burger, 1980). L. ovatus also appears from the lower Albian of Australia (Burger, 1980). The same assemblage was distinguished in Hole 327 (Falkland Plateau, Leg 36) from the interval 341-368 meters. Its age was determined to be Albian (Hedlund and Beju, 1977). The assemblage of planktonic foraminifers in Cores 57-55 confirms the lower Albian age of these sediments, including Assemblage III (the Ticinella roberti Zone).

\section{CORRELATION OF UPPER JURASSIC SEDIMENTS AT SITES 511 AND 330}

Because of drilling restrictions, Site 511 did not reach the crystalline basement. Site 330 of Leg 36, drilled on 
the Falkland Plateau $10 \mathrm{~km}$ from Site 511, did penetrate Jurassic sediments and crystalline rock. Harris (1977), using the data on microplankton, spores, and pollen at Site 330, determined the age of the sediments in the interval from 300 to 550 meters (Cores 5-15) as OxfordianKimmeridgian, when compared to those on the Australian continent. Other researchers (Hedlund and Beju, 1977) identified two assemblages in this interval; one, in the interval 315-440 meters (Cores 6-11), was determined to be Oxfordian-Kimmeridgian, the other, at a depth of 525 meters (Core 14), to be Middle Jurassic. As these authors used mostly dinoflagellate cysts to determine the age of Jurassic sediments at Site 330, it is worthwhile to correlate palynoassemblages from Sites 330 and 511, since Site 330 penetrated older sediments.

The preliminary study of spores and pollen from samples of Site 330 in the interval 315-525 meters (Cores 6-14) enabled us to distinguish three assemblages. The results of the palynological analysis are summarized in Table 2. The assemblage identified in the interval from 315 to $\mathbf{4 4 0}$ meters (Cores 6-11) proved similar to Assemblage I of Site 511. It abounds in pollen of Classopollis (23.0-58.5\%) and Vitreisporites pallidus (16.5-47.0\%). Bisaccate and trisaccate conifer pollen and pollen of Callialasporites trilobatus, C. dampieri, and C. segmentatus are present throughout the assemblage. Very rare specimens of Ephedripites sp. 1, E. sp. 3, Sulcosaccispora sp., and Monosaccites sp. 1 were found. Spores are not numerous $(5.0-15.0 \%)$, and are represented by Antulsporites saevus, A. varigranulatus, Contignisporites cooksonii, Dictyophyllidites sp., Dictyotosporites complex, Ischyosporites marburgensis, I. volkheimeri, Klukisporites lacunus, Marattisporites scabratus, Matonisporites crassiangulatus, Interulobites algoensis, I. sinuosus, and $I$. sp. A. In Sample 330-6-1, 43-47 cm, very rare spores of Cicatricosisporites sp. were observed.

All of the species listed are characteristic of the Upper Jurassic assemblage of Site 511. The similarity lies in the presence of common species of spores and pollen, including spores of $I$. algoensis and I. sinuosus, E. sp. 1, and $E$. sp. 3. These species are not representative of the Oxfordian-Kimmeridgian of Australia but can be observed in the uppermost parts of the Upper Jurassic of Argentina and South Africa. The presence of very rare specimens of spores of the genus Cicatricosisporites in Sample 330-6-1, 43-47 cm also suggests the uppermost Jurassic. Rare specimens of these spores have been found in the uppermost parts of the Upper Jurassic but have never been observed in assemblages from Oxfordian-Kimmeridgian deposits.

The composition of the assemblage from Samples 330$12-2,86-87 \mathrm{~cm}$ to $330-13-4,116-120 \mathrm{~cm}$ remains approximately the same as the Tithonian assemblage just described. Nevertheless, no spores of $I$. algoensis and $I$. sinuosus or pollen of $E$. sp. 1 and $E$. sp. 3 were observed here. This assemblage is characterized by presence of spores of $I$. sp. A., Verrucosisporites sp. E., V. sp. 1, Trilites sp. 2, and a large trisaccate pollen of Podosporites $\mathrm{sp}$. 1. I. sp. A. and $V$. sp. E. have been described by Volkheimer and Quattrochio (1975) from the Tithonian of Argentina. However, their complete stratigraphic distribution is not known: the Oxfordian-Kimmeridgian palynoassemblages in Argentina and South Africa have not been studied, and these spores may occur in pre-Tithonian deposits. The exact dating of this assemblage is not possible at present.

The assemblage from Samples 330-14-4, 70-74 cm, $330-14-3,92-96 \mathrm{~cm}$, and $330-14-2,18-31 \mathrm{~cm}$ is rather clearly characterized by a higher content of Gleicheniidites spores (up to $16 \%$ ), and the presence of the spores Polycingulatisporites striatus, Polypodiaceoisporites neuquenensis, and Ischyosporites crateris. This assemblage may be transitional between the Middle and Late Jurassic: $P$. neuquenensis has been described from the Middle Jurassic of Argentina (Volkheimer, 1968) and Polycingulatisporites striatus from Middle-Upper Jurassic deposits of Australia (Filatoff, 1975). I. crateris has been found in Upper Jurassic sediments of Australia, the Lower and Middle Jurassic of France, and the Middle Jurassic of Sweden (Filatoff, 1975).

Thus, correlation of sediments from Sites 330 and 511 leads to the following preliminary conclusions:

1) Five successive palynoassemblages in a section of Jurassic and Lower Cretaceous sediments have been distinguished (from bottom to top):

a) Middle-Upper Jurassic (Site 330)

b) Upper Jurassic, pre-Tithonian (Site 330)

c) Tithonian (Sites 330 and 511)

d) Neocomian-Aptian (Site 511)

e) lower Albian (Site 511).

It is quite possible, however, that between the Upper Jurassic and Lower Cretaceous there is a hiatus and that the lowest parts of the Cretaceous or uppermost parts of the Jurassic are absent from the section. That hiatus may exist between deposits dated by us as NeocomianAptian and early Albian. Thus we must determine the age of these Mesozoic sediments more exactly, through correlation with surface sections containing marine faunas and thoroughly studied palynoassemblages.

2) The presence of sediments transitional between the Middle and Upper Jurassic at Site $\mathbf{3 3 0}$ shows that the subsidence of the Falkland Plateau began at the boundary of Middle and Late Jurassic time.

\section{COMPARISON OF UPPER JURASSIC AND LOWER CRETACEOUS PALYNOASSEMBLAGES OF THE FALKLAND PLATEAU, SOUTH AMERICA, WEST AND SOUTH AFRICA, AND AUSTRALIA}

According to palynological data, a pronounced climatic zonation existed within the Atlantic realm in Late Jurassic and Early Cretaceous times. In the south, the assemblages most similar to those at Sites 511 and 330 are spore and pollen assemblages from Argentina and South Africa. Upper Jurassic assemblages of these countries are characterized by abundance of Classopollis pollen, very rare Ephedripites, the presence of bisaccate and trisaccate conifers, and spores of the genus Interulobites. Pollen of Cyclusphaera psilata and spores of $C y$ atheacidites tectifera, Muricingulisporis annulatus, and Polypodiaceoisporites elegans are representative only of Lower Cretaceous deposits of these regions. 
Table 2. Percentage of spores and pollen in Jurassic sediments, Hole 330.

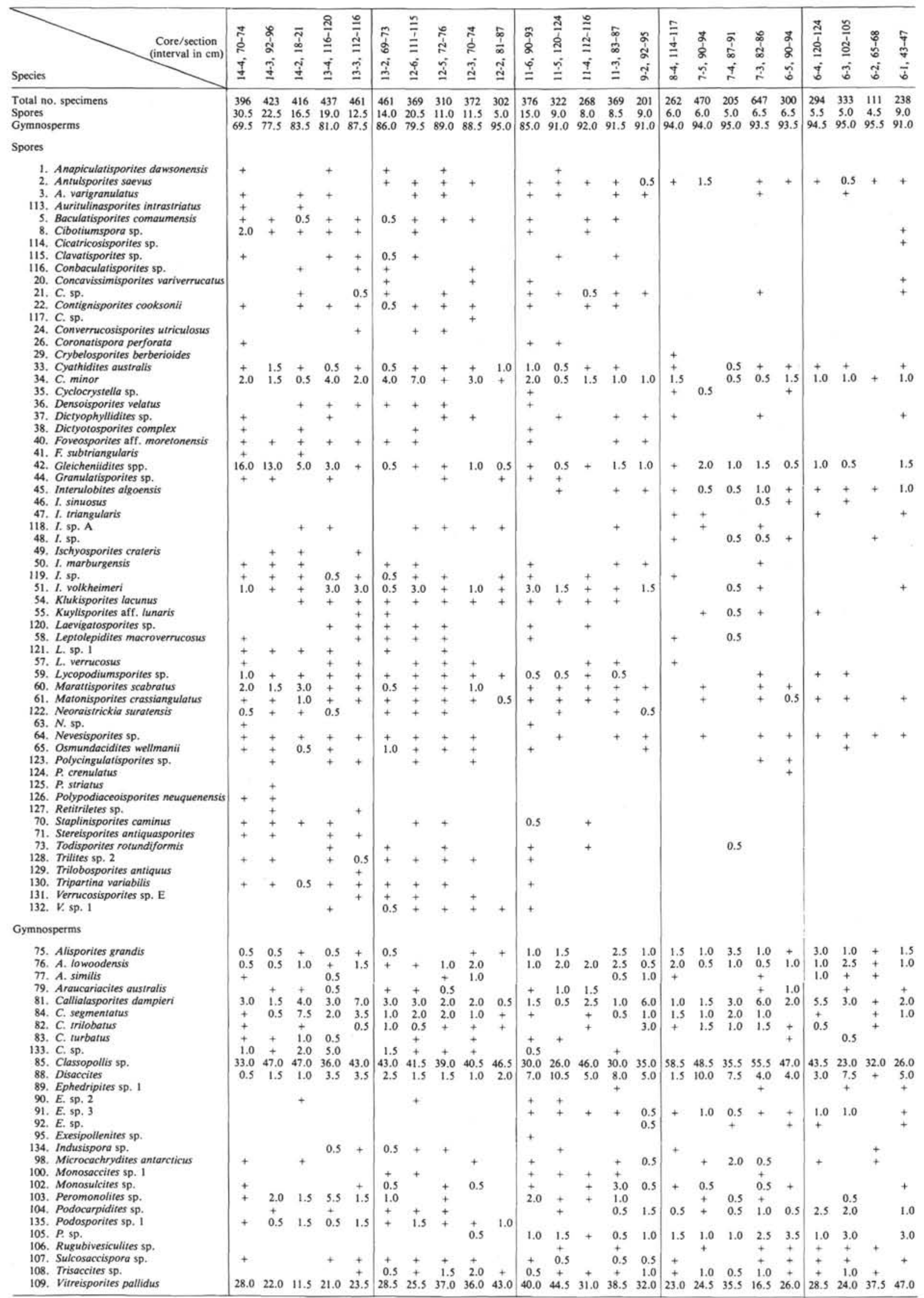

Note: Number before the species name denotes the ordinal number in the taxonomic list. + indicates content less than $0.5 \%$ 
The lower Albian is also characterized by a rather high content of Classopollis pollen, by the appearance of Crybelosporites aff. striatus, C. sp. 1, Laevigatosporites ovatus, Cyatheacidites sp. 1, considerable numbers of Gleicheniidites spores, and very rare specimens of the angiosperm pollen Clavatipollenites.

In Australia the palynoassemblages of the uppermost Jurassic and Neocomian are characterized by the small amount of Classopollis pollen and the presence of $\mathrm{Mu}$ rospora florida. In addition, there are a number of species peculiar to the Neocomian of Australia, and not observed in Argentina and South Africa: Cyclosporites hunghesii, Crybelosporites stylosus, and Dictyotosporites speciosus. The lower Albian of Australia is characterized by the small number of Classopollis and Gleicheniidites specimens. Some species from the lower Albian of Australia are also observed at Site 511: L. ovatus, Crybelosporites striatus, Clavatipollenites sp.

So, despite a number of endemic species characteristic only of Argentina and South Africa on the one hand, and Australia on the other, there is a certain similarity among assemblages in these territories. This similarity is seen in the presence of common species of bisaccate and trisaccate conifer pollen, very rare findings of Ephedripites, and some common species of spores.

Assemblages from the more northerly regions of the South Atlantic (Brazil, Western Africa) are significantly different from those of the Falkland Plateau, Argentina, and South Africa. Palynoassemblages from Upper Jurassic sediments of these regions are not known.

In Neocomian assemblages, as well as in those of the South Atlantic, Classopollis pollens are dominant, bisaccate conifer pollens occur as very rare specimens, and trisaccate pollens are totally absent. Ephedripites pollen is representative and diverse. Fern spores from a great number of species are present; Cicatricosisporites spores are especially diverse. A typical form for these regions is pollen of Dicheiropollis etruscus, which was recognized in Neocomian sediments of the coastal regions of Brazil and West Africa (Angola, Congo, Gabon) and at DSDP Sites 370 and 416 in the Morocco Basin but which is absent in Western Europe and the South Atlantic. The lower Albian of Brazil and West Africa is characterized by the presence of tricolpate grains of angiosperms, a great diversity of Ephedripites pollen, and rare spores with no representatives of species common in the lower Albian of Argentina.

The abundance of pollen of the genus Classopollis is thus typical of the Lower Cretaceous of Brazil, West Africa, Argentina, and South Africa. Data indicate that plants producing this pollen grew on seashores. Some researchers believe that these plants were of the same type as modern mangroves and formed brushwoods in the river deltas (Hughes, 1973); others believe they grew both on the near-shore slopes and on the elevations themselves (Vakhrameev, 1970, 1980).

In Brazil and West Africa a great amount of Classopollis is associated with a diversity of Ephedripites pollen and fern spores, pollen of other conifers being almost totally absent. In South Africa and Argentina the abundance of Classopollis is related to the presence of pollen of bisaccate and trisaccate conifers, a few spores of ferns, and very rare pollen of Ephedripites. Judging from the data of Jardiné et al. (1974), who observed the distribution of $D$. etruscus pollen in the regions adjacent to the Atlantic Ocean, a latitudinal belt covering West Africa and Brazil existed during the Neocomian. There was an abundance of Classopollis, diverse Ephedripites, and an almost complete absence of conifers. Deposition of salts in the Early Cretaceous within this belt testifies to a hot, dry climate.

This belt existed during the Albian as well, as shown by a peculiar angiosperm palynoflora found in Brazil and in West Africa up to the Angola Basin. At that time, West Africa and Brazil were situated near one another, and the southern boundary of the belt distinguished by Jardiné et al. (1974) may have passed between the Angola and Cape basins - a theory confirmed by DSDP data obtained in those basins. The assemblages from Albian sediments at Site 364 in the Angola Basin (Morgan, 1978) resemble synchronous assemblages from Senegal and the Ivory Coast (Jardiné and Magloire, 1965) and to Albian assemblages from Brazil (Herngreen, 1973). Aptian-Albian or Aptian assemblages in the Cape Basin at Site 361 tend to resemble Lower Cretaceous ones from Argentina and South Africa (McLachlan and Pieterse, 1978). The climate in Argentina and South Africa during the Neocomian-Aptian appears to have been dry but more moderate; this is evidenced by the scarcity of ferns and the numerous coniferous pollen with saccates. Data obtained from Sites 511 and 327, which show that the number of spores and ferns in the lower Albian increased sharply, testify to a more humid climate at that time.

\section{TAXONOMIC LIST}

Spores

1. Anapiculatisporites dawsonensis Reiser and Williams, 1969 (Plate 3, Fig. 21). Lower-Upper Jurassic of Australia (Filatoff, 1975).

2. Antulsporites saevus (Balme) Archangelsky and Gamerro, 1966 (Plate 2, Figs. 11-15). Lower-Upper Jurassic of Australia (Balme, 1957; Filatoff, 1975); Jurassic-Lower Cretaceous of Argentina (Archangelsky and Gamerro, 1966; Volkheimer, 1968).

3. Antulsporites varigranulatus (Levet-Carette) Reiser and Williams, 1969 (Plate 2, Figs. 16-18). Lower Jurassic of France (Levet-Carette, 1963); Lower-Upper Jurassic of Australia (Filatoff, 1975).

4. Appendicisporites sp. (Plate 7, Fig. 8).

5. Baculatisporites comaumensis (Cookson) Potonié, 1956. (Plate 3, Fig. 27). Worldwide distribution in Mesozoic sediments.

6. Biretrisporites sp. (Plate 5, Figs. 12-13).

7. Ceratosporites distalgranulatus (Couper) Kemp, 1970 (Plate 5, Figs. 4-6). Upper Aptian-upper Albian of England (Kemp, 1970).

8. Cibotiumspora sp.

9. Cicatricosisporites australiensis (Cookson) Potonié, 1956 (Plate 7, Figs. 12-14). Worldwide distribution in Cretaceous sediments; Tithonian-Berriasian of West Europe (Dornhöfer and Norris, 1977).

10. Cicatricosisporites hallei Delcourt and Sprumont, 1955 (Plate 7, Figs. 16-18). Worldwide distribution in Lower Cretaceous.

11. Cicatricosisporites hughesi Dettmann, 1963 (Plate 7, Fig. 15). Lower-upper Cretaceous of Australia (Dettmann, 1963; Burger, 1968, 1973, 1975, 1980); upper Cretaceous of North America (Drugg, 1967; Groot et al., 1961).

12. Cicatricosisporites ludbrooki Dettmann, 1963 (Plate 7, Figs. 9-11). Lower Cretaceous of Australia (Dettmann, 1963; Burger, 
1972); Aptian-Albian of Canada (Brideaux and McIntyre, 1975).

13. Cicatricosisporites proxiradiatus Kemp, 1970 (Plate 7, Figs. 19-20). Aptian-Albian of England (Kemp, 1970).

14-18. Cicatricosisporites sp. 1-5 (Plate 8, Figs. 1-13).

19. Cingutriletes clavus (Balme) Dettmann, 1963 (Plate 5, Fig. 14). Worldwide distribution in Cretaceous sediments.

20. Concavissimisporites variverrucatus (Couper) Brenner, 1963 (Plate 1, Fig. 11). Worldwide distribution in upper Mesozoic sediments.

21. Concavissimisporites sp. (Plate 1, Fig. 10).

22. Contignisporites cooksonii (Balme) Dettmann, 1963 (Plate 2, Figs. 21-23). Worldwide distribution in Upper Jurassic and Lower Cretaceous.

23. Contignisporites fornicatus Dettmann, 1963 (Plate 2, Figs. 1920). Cretaceous of Australia (Dettmann, 1963; Burger, 1973, 1974, 1980).

24. Converrucosisporites utriculosus (Krasnova) Pocock, 1970 (Plate 3, Figs. 22-23). Upper Jurassic of Canada (Pocock, 1970), Middle Jurassic of Sweden (Guy-Ohlson, 1976).

25. Coronatispora valdensis (Couper) Dettmann, 1963 (Plate 4, Figs. 1-2). Lower Cretaceous of England (Couper, 1958; Kemp, 1970); Aptian-Albian of Canada (Brideaux and McIntyre, 1975).

26. Coronatispora perforata Dettmann, 1963 (Plate 4, Fig. 3). Upper Jurassic-Lower Cretaceous of Australia (Dettmann, 1963; Filatoff, 1975).

27. Crybelosporites aff. striatus (Cookson and Dettmann) Dettmann, 1963 (Plate 6, Figs. 1-9). Lower Cretaceous of Australia (Dettmann, 1963; Burger, 1980).

28. Crybelosporites sp. 1 (Plate 6, Figs. 10-17). Cavate forms with very thin reticulate exine. Found only in lower Albian assemblages.

29. Crybelosporites berberioides Burger, 1976 (Plate 4, Figs. 19-21). Lower Cretaceous of Australia (Burger, 1976, 1980).

30. Cyatheacidites tectifera Archangelsky and Gamerro, 1966 (Plate 7, Figs. 1-2). Lower Cretaceous of Argentina (Archangelsky and Gamerro, 1967); Lower Cretaceous of Cape Basin (McLachlan and Pieterse, 1978).

31. Cyatheacidites sp. 1 (Plate 7, Figs. 3-4) Forms differ from $C$. tectifera; perforate distally.

32. Cyatheacidites sp. 2 (Plate 7, Figs. 5-7). Forms differ from $C$. tectifera; verrucate distally.

33. Cyathidites australis Couper, 1953 (Plate 1, Figs. 1-2). Worldwide distribution in Mesozoic sediments.

34. Cyathidites minor Couper, 1953 (Plate 1, Figs. 3-4). Worldwide distribution in Mesozoic sediments.

35. Cyclocrystella sp. (Plate 2, Fig. 24). A single specimen only was found in Sample 511-63-1, 130-134.

36. Densoisporites velatus Weyland and Krieger, 1953 (Plate 4, Fig. 4). Worldwide distribution in upper Mesozoic sediments.

37. Dictyophyllidites sp. (Plate 1, Figs. 5-6).

38. Dictyotosporites complex Cookson and Dettmann, 1958 (Plate 3, Figs. 25-26). Wide distribution in Mesozoic sediments of Australia.

39. Distaltriangulisporites pelliculus Scott, 1976 (Plate 4, Figs. 11-12). Upper Valanginian-lower Hauterivian of the Algoa Basin, South Africa (Scott, 1976).

40. Foveosporites moretonensis de Jersey, 1964 (Plate 2, Fig. 10). Wide distribution in upper Mesozoic of Australia.

41. Foveosporites subtriangularis (Brenner) Doring, 1966 (Plate 2, Figs. 8-9). Worldwide distribution in upper Mesozoic sediments.

42. Gleicheniidites senonicus Ross, 1949 (Plate 1, Fig. 13). Worldwide distribution in Mesozoic sediments.

43. Gleicheniidites spp. (Plate 5, Figs. 7-10). Large forms; there may be more than one species of Gleicheniidites. Found only in the lower Albian Assemblage III.

44. Granulatisporites sp. (Plate 1, Fig. 12).

45. Interulobites algoensis Scott, 1976 (Plate 3, Figs. 12-13). Upper Jurassic-Lower Cretaceous of the Algoa Basin in South Africa (Scott, 1976).

46. Interulobites sinuosus Scott, 1976 (Plate 3, Figs. 14-17). Lower Cretaceous of the Algoa Basin in South Africa (Scott, 1976);
Lower Cretaceous of the Cape Basin (McLachlan and Pieterse, 1978).

47. Interulobites triangularis (Brenner) Paden et al., 1971 (Plate 3 , Figs. 10-11). Lower Cretaceous of U.S.A. (Paden et al., 1971); Upper Jurassic-Lower Cretaceous of the Algoa Basin in South Africa (Scott, 1976).

48. Interulobites $s p$. (Plate 3, Figs. 18-20).

49. Ischyosporites crateris Balme, 1957. Upper Mesozoic of Australia (Balme, 1957; Filatoff, 1975); Middle Jurassic of Argentina (Volkheimer, 1974).

50. Ischyosporites marburgensis de Jersey, 1963 (Plate 1, Figs. 20-21). Lower-Middle Jurassic of Australia (Filatoff, 1975); Middle Jurassic of Argentina (Volkheimer, 1974).

51. Ischyosporites volkheimeri Filatoff, 1975 (Plate 3, Figs. 1-6). Lower-Upper Jurassic of Australia (Filatoff, 1975); Callovian of Argentina (Volkheimer, 1972).

52. Ischyosporites sp. 1 (Plate 5, Figs. 16-18).

53. Ischyosporites sp. 2 (Plate 5, Figs. 19-20).

54. Klukisporites lacunus Filatoff, 1975 (Plate 1, Fig. 22). MiddleUpper Jurassic of Australia (Filatoff, 1975).

55. Kuylisporites lunaris Cookson and Dettmann (Plate 5, Figs. 1-3). Worldwide distribution in Lower Cretaceous sediments.

56. Laevigatosporites ovatus Wilson and Webster, 1946 (Plate 5, Fig. 11). Albian-Cenomanian of Australia (Dettmann, 1963); Cenomanian of U.S.A. (Hedlund, 1966).

57. Leptolepidites verrucatus Couper, 1953 (Plate 2, Figs. 1-5). Worldwide distribution in Jurassic and Lower Cretaceous sediments.

58. Leptolepidites macroverrucosus Schulz, 1967 (Plate 2, Figs. 6-7). Lower Jurassic of Germany (Schulz, 1967), TithonianLower Cretaceous of Argentina (Volkheimer and Quattrocchio, 1975).

59. Lycopodiumsporites sp. (Plate 1, Figs. 16-17).

60. Marattisporites scabratus Couper, 1958 (Plate 1, Fig. 15). Worldwide distribution in upper Mesozoic sediments.

61. Matonisporites crassiangulatus (Balme) Dettmann, 1963 (Plate 1, Figs. 7-9). Worldwide distribution in upper Mesozoic sediments.

62. Muricingulisporis annulatus Archangelsky and Gamerro, 1966 (Plate 6, Figs. 18-21). Lower Cretaceous of Argentina (Archangelsky and Gamerro, 1966).

63. Neoraistrickia sp. (Plate 3, Fig. 24).

64. Nevesisporites sp. (Plate 3, Figs. 7-9).

65. Osmundacidites wellmanii Couper, 1953 (Plate 3, Fig. 28). Worldwide distribution in Mesozoic sediments.

66. Patellasporites sp. (Plate 4, Fig. 18).

67. Perotrilites linearis (Cookson and Dettmann) Evans, 1970 (Plate 5, Figs. 21-24). Cretaceous of Australia (Dettmann, 1963; Burger, 1975).

68. Polypodiaceoisporites elegans Archangelsky and Gamerro, 1966 (Plate 4, Figs. 5-9). Lower Cretaceous of Argentina (Archangelsky and Gamerro, 1967).

69. Sestrosporites pseudoalveolatus (Couper) Dettmann, 1963 (Plate 4, Fig. 10). Worldwide distribution in upper Mesozoic sediments.

70. Staplinisporites caminus (Balme) Pocock, 1962 (Plate 1, Figs. 18-19).

71. Stereisporites antiquasporites (Wilson and Webster) Dettmann, 1963 (Plate 5, Fig. 15). Worldwide in upper Mesozoic sediments.

72. Taurocusporites segmentatus Stower, 1962 (Plate 4, Figs. 1314). Worldwide distribution in Lower Cretaceous sediments.

73. Todisporites rotundiformis (Maljavkina) Pocock, 1970 (Plate 1, Fig. 14). Lower-Middle Jurassic of Canada.

74. Trilites sp. 1. (Plate 4, Figs. 15-17).

\section{Gymnosperm Pollen}

75. Alisporites grandis (Cookson) Dettmann, 1963 (Plate 10, Figs. 14-15). Worldwide distribution in upper Mesozoic sediments.

76. Alisporites lowoodensis de Jersey, 1963 (Plate 10, Figs. 10-11). Triassic-Jurassic of Australia (Hill et al., 1966; Filatoff, 1975).

77. Alisporites similis (Balme) Dettmann, 1963 (Plate 10, Fig. 12). Lower Jurassic-Lower Cretaceous of Australia (Balme, 1957; Dettmann, 1963; de Jersey, 1971; McKellar, 1974). 
78. Alisporites sp. (Plate 10, Fig. 13).

79. Araucariacites australis (Cookson) Couper, 1953 (Plate 12, Fig. 3). Worldwide distribution in upper Mesozoic sediments.

80. Bisacado sp. A (Plate 9, Figs. 23-26). Lower Cretaceous of Argentina (Volkheimer et al., 1977).

81. Callialasporites dampieri (Balme) Dev, 1961 (Plate 11, Fig. 7). Worldwide distribution in Mesozoic sediments.

82. Callialasporites trilobatus (Balme) Dev, 1961 (Plate 11, Figs. 89). Worldwide distribution in Mesozoic sediments.

83. Callialasporites turbatus (Balme) Schulz, 1967 (Plate 11, Figs. 10-11). Worldwide distribution in Mesozoic sediments.

84. Callialasporites segmentatus (Balme) Srivastava, 1963 (Plate 11, Fig. 12).

85. Classopollis spp. (Plate 12, Figs. 4-7).

86. Cyclusphaera psilata Volkheimer and Sepúlveda, 1976 (Plate 12, Figs. 8-11). Hauterivian-lower Albian of Argentina (Volkheimer and Sepúlveda, 1976; Volkheimer et al., 1977).

87. Cyclusphaera sp. A (Plate 12, Figs. 12-15). Hauterivian-Barremian of Argentina (Volkheimer et al., 1977).

88. Disaccites (Plate 10, Figs. 18-19; Plate 11, Figs. 1-6).

89. Ephedripites sp. 1 (Plate 8, Figs. 23-25).

90. Ephedripites sp. 2 (Plate 8, Figs. 17-19).

91. Ephedripites sp. 3 (Plate 8, Figs. 20-22)

92. Ephedripites spp. (Plate 9, Figs. 3-8).

93. Ephedripites sp. 5 (Plate 9, Figs. 1-2).

94. Eucommiidites sp.

95. Exesipollenites sp. (Plate 11, Fig. 13).

96. Inaperturopollenites limbatus Balme, 1957 (Plate 12, Fig. 1). Lower Cretaceous of Australia, Argentina, Cape Basin (Balme, 1957; Archangelsky and Gamerro, 1967; Volkheimer et al., 1977; McLachlan and Pieterse, 1978).

97. Inaperturopollenites sp. (Plate 12, Fig. 2).

98. Microcachryidites antarcticus Cookson, 1947 (Plate 10, Figs. 2-4). Jurassic-Lower Cretaceous of Australia, Argentina (Balme, 1957; Dettmann, 1963; Burger, 1972; Archangelsky and Gamerro, 1967; Volkheimer, 1968).

99. Microcachryidites sp. (Plate 10, Fig. 5).

100. Monosaccites sp 1 (Plate 9, Figs. 13-14).

101. Monosaccites sp. 2 (Plate 9, Figs. 11-12).

102. Monosulcites sp. (Plate 8, Figs. 14-16).

103. Peromonolites sp. (Plate 11, Figs. 14-15).

104. Podocarpidites sp. (Plate 10, Figs. 16-17).

105. Podosporites sp. (Plate 10, Figs. 6-9).

106. Rugubivesiculites sp. (Plate 9, Figs. 17-20).

107. Sulcosaccispora sp. (Plate 9, Figs. 15-16).

108. Trisaccites $\mathrm{sp}$. (Plate 10, Fig. 1).

109. Vitreisporites pallidus (Reissinger) Nilsson, 1958 (Plate 9, Figs. 21-22). Worldwide distribution in Mesozoic sediments.

110. Steevesipollenites sp. (Plate 9, Figs. 9, 10).

\section{Angiosperm Pollen}

111. Clavatipollenites incisus Chlonova, 1977 (Plate 12, Figs. 18-19). Albian-Cenomanian of West Siberia (Chlonova, 1977).

112. Clavatipollenites rotundus Kemp, 1968 (Plate 12, Figs. 16-17). Worldwide distribution in Albian sediments.

\section{Additional Taxons from Site 330}

113. Auritulinasporites intrastriatus Nilsson, 1958 (Plate 13, Figs. 1-2). Lower and Middle Jurassic of Sweden (Tralau and Artursson, 1971).

114. Cicatricosisporites sp. (Plate 15, Fig. 12)

115. Clavatisporites sp. (Plate 13, Figs. 6-7).

116. Conbaculatisporites sp. (Plate 14, Figs. 14-17).

117. Contignisporites sp. (Plate 14, Figs. 9-10).

118. Interulobites sp. A Volkheimer and Quattrochio, 1975 (Plate 13, Figs. 10-13). Tithonian of Argentina (Volkheimer and Quattrochio, 1975).

119. Ischyosporites sp. (Plate 14, Fig. 21).

120. Laevigatosporites sp. (Plate 15, Fig. 2)

121. Leptolepidites sp. 1 (Plate 13, Figs. 18-21).

122. Neoraistrickia suratensis McKellar, 1974 (Plate 14, Figs. 5-7). Lower Jurassic of Australia (McKellar, 1974); Middle-Upper Jurassic of Australia (Filatoff, 1975).

123. Polycingulatisporites sp. (Plate 14, Fig. 13).
124. Polycingulatisporites crenulatus Playford and Dettmann, 1965 (Plate 14, Fig. 11). Worldwide distribution in upper Triassic and Jurassic sediments.

125. Polycingulatisporites striatus Filatoff, 1975 (Plate 14, Fig. 12). Middle-Upper Jurassic of Australia (Filatoff, 1975).

126. Polypodiaceoisporites neuquenensis Volkheimer, 1969 (Plate 13, Figs. 3-4). Middle Jurassic of Argentina.

127. Retitriletes sp. (Plate 13, Figs. 8-9).

128. Triletes sp. 2 (Plate 13, Fig. 5).

129. Trilobosporites antiquus Reiser and Williams, 1969 (Plate 15, Fig. 11). Jurassic of Australia.

130. Tripartina variabilis. Worldwide distribution in Mesozoic sediments.

131. Verrucosisporites sp. E Volkheimer and Quattrochio, 1975 (Plate 14, Figs. 1-3). Tithonian of Argentina (Volkheimer and Quattrochio, 1975)

132. Verrucosisporites sp. 1 (Plate 14, Fig. 4).

133. Callialasporites sp. (Plate 15, Fig. 22).

134. Indusispora sp. (Plate 15, Fig. 18).

135. Podosporites sp. 1. (Plate 15, Figs. 20-21).

\section{ACKNOWLEDGMENTS}

The author is very grateful to Professor V. A. Vakhrameev and Dr. N. A. Volkova for critical comments concerning the paper and thanks V. K. Bolshakova for maceration of samples and A. I. Nazarov for microphotographs. She is also very much obliged to the U.S. National Science Foundation and the Deep Sea Drilling Project for the samples from Site 330, Leg 36, used as comparative material.

\section{REFERENCES}

Archangelsky, S., and Gamerro, J., 1965. Estudio palinologico de la Formacion Baquero (Cretacico), Provincia de Santa Cruz. 1. Ameghiniana, 4(No. 5):159-167.

1966. Estudio palinologico de la Formacion Baquero (Cretacico), Provincia de Santa Cruz. 11. Ameghiniana, 4(No. 6): 201-209.

1967. Spore and pollen types of the Lower Cretaceous in Patagonia (Argentina), Rev. Palaeobot. Palynol., 1:211-218.

Balme, B. E., 1957. Spores and Pollen Grains from the Mesozoic of Western Australia. CSIRO Div. Coal Res. Ref. T. C. 25.

Brenner, G. J., 1963. The Spores and Pollen of the Potomac Group of Maryland. Md. Dep. Geol., Mines Water Resour. Bull. 27.

Brideaux, W. W., and McIntyre, D. J., 1975. Miospores and Microplankton from Aptian-Albian Rocks along Horton River, District of Mackenzie. Bull. Geol. Surv. Can., 252.

Burger, D. 1973. Palynological Observations in the Carpentaria Basin, Queensland. Aust. Bur. Miner. Resour. Bull. 116.

1974. Palynology of the subsurface Lower Cretaceous strata in the Surat Basin, Queensland. Bull. Bur. Miner. Resour. Geol. Geophys. Aust., 150:27-42.

1975, Cenomanian spores and pollen grains from Bathurst Island, Northern Territory, Australia. Bull. Bur. Miner. Resour. Geol Geophys. Aust., 151:114-169.

1976. Some Early Cretaceous plant microfossils from Queensland. Bull. Bur. Miner. Resour. Geol. Geophys. Aust., 160:1-22.

1980. Palynological Studies in the Lower Cretaceous of the Surat Basin, Australia. Bull. Bur. Miner. Resour. Geol. Geophys. 189.

Chlonova, A. F., 1977. First finding of the pollen of Clavatipollenites in West Siberian Cretaceous deposits. Paleontol. Zhur., 2:115-121.

Cookson, I. C., 1947. Plant microfossils from the lignites of Kerguelen Archipelago. Repts. B.A.N.Z. Antarctic Res. Exp. (192931) Ser. A, 2(8):127-142.

Cookson, I., and Dettmann, M., 1958. Some trilete spores from upper Mesozoic deposits in the Eastern Australian region. Proc. $R$. Soc. Vic., 70:95-128.

Couper, R. A., 1958. British Mesozoic microspores and pollen grains: A systematic and stratigraphic study. Palaeontographica, B, 103: 75-179.

Davey, R., 1978. Marine Cretaceous palynology of Site 361, DSDP Leg 40, off Southwestern Africa. In Bolli, H. M., Ryan, W. B. F., et al., Init. Repts. DSDP, 40: Washington (U.S. Govt. Printing Office), 883-914. 
De Jersey, N. J., 1971. Early Jurassic Miospores from the Helidon Sandstone. Publ. Geol. Surv. Queensl., 351, Palaeont. Pap. 25.

Delcourt, A. and Sprumont, G., 1955. Les spores et Grains de pollen du Wealden du Hainaut. Mem. Soc. Belge. Géol. Paléont. Hydrol. N.S. $4,5$.

Dettmann, M. E., 1963. Upper Mesozoic microfloras from Southeastern Australia. Proc. R. Soc. Vict. 77(1):1-173.

Dev, Sukh, 1961. The fossil flora of the Jabalpur Series. 3. Spores and pollen grains. Palaeobotanist, 8(1.2):43-56.

Dorhöfer, G. and Norris, G., 1977. Discrimination and correlation of highest Jurassic and lowest Cretaceous terrestrial palynofloras in North-West Europe. Palynology, 1:79-93.

Döring, H., 1966. Sporenstratigraphischer Vergleich zwischen dem Wealden Norddeutschlands und Südenglands. Geol. Beih. 55: 102-129.

Drugg, W. S., 1967. Palynology of the Upper Moreno Formation (Late Cretaceous-Paleocene) Escarpado Canyon, California. $\mathrm{Pa}$ laeontographica, $B, 120: 1-71$.

Filatoff, J., 1975. Jurassic palynology of the Perth Basin, Western Australia. Paleontographica, B, 154:1-113.

Groot, J. J., Penny, J. S., and Groot, C. R., 1961. Plant microfossils and the age of the Raritan, Tuscaloosa and Magothy Formations of the eastern United states. Palaeontographica, B, 108:121-140.

Guy-Ohlson, D., 1976. Additional palynomorphs from the Middle Jurassic of the Vilhemsfält boring, Southern Sweden. Stockholm Contrib. Geol., 30(3):81-94.

Harris, W. K., 1977. Palynology of cores from Deep Sea Drilling Sites 327,328 , and 330 , South Atlantic Ocean. In Barker, P. F., Dalziel, I. W. D., et al., Init. Repts. DSDP, 36: Washington (U.S. Govt. Printing Office), 761-816.

Hedlund, R. W., 1966. Palynology of the Red Branch Member of the Woodbine Formation (Cenomanian), Bryan County, Oklahoma. Bull. Okl. Geol. Surv., 112

Hedlund, R. W., and Beju, D., 1977. Stratigraphic palynology of selected Mesozoic samples, DSDP Hole $327 \mathrm{~A}$ and Site 330. In Barker, P. F., Dalziel, I. W. D., et al., Init. Repts. DSDP, 36: Washington (U.S. Govt. Printing Office), 817-828

Herngreen, G., 1973. Palynology of Albian-Cenomanian strata of borehole I-QS-I-MA, state of Maranhão, Brazil: Pollen et Spores, 15:515-555.

Hill, D., Playford, G., and Woods, J., 1966. Jurassic Fossils of Queensland. Queensl. Paleontogr. Soc.

Hughes, N. F., 1973. Palynological time-correlation of English Wealden with boreal marine successions. In Casey, R., and Rowson, P. F. (Eds.), The Boreal Lower Cretaceous. Geol. J. Special Issue No. 5: Liverpool (Seal House Press), pp. 185-192.

Jardiné, S., Biens, P., and Doerenkamp, A., 1974. Dicheiropollis etruscus, un pollen caractéristique du Crétacé inférieur afro-sudaméricain. Conséquences pour l'évaluation des unités climatiques et implications dans la dérive des continents. Sci. Geol. Bull. 27(No. 1-2):87-100.

Jardiné, S., and Magloire, L., 1965. Palynologie et stratigraphie du Crétacé des bassins du Sénégal et de Côte d'Ivoire. Mem. Bur. Rech. Geol. Min. (Fr.), 32:187-245.

Kemp, E. M., 1968. Probable angiosperm pollen from British Barremian to Albian strata. Palaeontology, 11:421-434. 1970. Aptian and Albian miospores from SouthernEngland. Paleontolographica, B 131(No. 1-4):73-143.

Levet-Carette, J., 1963. Etude de la microflore infraliasique d'une sondage effecturé dans le sous-sol de Boulogne-sur-Mer (Pas-deCalais). Ann. Soc. Geol. Nord., 83(2):101-128.

McKellar, J. L., 1974. Jurassic Miospores from the Upper Evergreen Formation, Hutton Sandstone, and Basal Injune Creek Group, Northeastern Surat Basin. Publ. Geol. Surv. Queensl., 361, Palaeont. Pap., 35.

McLachlan, I. R., and Pieterse, E., 1978. Preliminary palynological results: Site 361, Leg 40, Deep Sea Drilling Project. In Bolli, H. M., Ryan, W. B. F., et al., Init. Repts. DSDP, 40: Washington (U.S. Govt. Printing Office), 857-882.

Malumián, N., and Báez, A., 1976. Outline of Cretaceous stratigraphy of Argentina. Ann. Muséum Hist. Nat. Nice, 4, p. XXVII.1-10.

Morgan, R., 1978. Albian to Senonian palynology of Site 364, Angola Basin. In Bolli, H. M., Ryan, W. B. F., et al., Init. Repts. DSDP, 40: Washington (U.S. Govt. Printing Office), 915-952.
Nilsson, T., 1958. Uber das Vorkommen eines mesozoischen Sapropelgesteins in Schonen. Acta Univ. Lund. N. F., Avd. 2:1-112.

Paden Phillips, P., and Felix, C., 1971. A study of Lower and Middle Cretaceous spores and pollen from the southeastern United States. II. Pollen. Pollen et Spores, 13(3):447-473.

Playford, G., and Dettmann, M. E., 1965. Rhaeto-Liassic microfossils from the Leigh Creek Coal Measures, South Australia. Senckenbergiana Lethaea, 46(2/3):127-181.

Pocock, S. A. J., 1962. Microfossil analysis and age determination of Strata at the Jurassic-Cretaceous boundary in the western Canada plains. Palaeontographica, B, 111:1-95.

1970. Palynology of the Jurassic Sediments of western Canada. Part 1. Palaeontographica, B, 130:12-136.

Potonié, R., 1956. Synopsis der Gattungen der Sporae dispersae. I Teil: Sporites,. Beih. Geol. Jahrb., 23.

Reiser, R. F., and Williams, A. J., 1969. Palynology of the Lower Jurassic Sediments of the Northern Surat Basin. Publ. Geol. Surv. Queensl., 339, Palaeont. Pap., 15.

Ross, N. E., 1949. Investigations of the Senonian of the Kristiansand district, southern Sweden. I. On a Cretaceous pollen and spore bearing clay of Scania. Bull. Geol. Inst. Univ. Uppsala, 34: 27-43.

Schulz, E., 1967. Sporenpaläontologische Untersuchungen rätoliassischer Schichten im Zentralteil des Germanischen Beckens. Paläont., 2 B:541-633.

Scott, L., 1976. Palynology of Lower Cretaceous deposits from the Algoa Basin (Republic of South Africa). Pollen et Spores, 18:(No. 4):563-609.

Srivastava, S. K., 1963. Polospores from Jurassics of Rajasthan, India. Nature, 198(4887):1323-1324.

Stover, L. E., 1962. Taurocusporites, a new trilete spore genus from the Lower Cretaceous of Maryland. Micropaleontology, 8:55-59.

Tralau, H., and Artursson, K., 1972. New middle Jurassic pollen and spore floras from southern Sweden and the Oresund. Grana Palynol., 12:57-63.

Vakhrameev, V. A., 1970. Regularities in the distribution paleoecology of Mesozoic coniferous Cheirolepidiaceae. Paleontol. Zhur., No. 1,19-34. (In Russian)

1980. Pollen Classopollis as an indicator of Jurassic and Cretaceous climates. Sov. Geol., No. 8:48-56. (In Russian)

Volkheimer, W., 1968. Esporas y granos de polen del Jurasico de Neuquén (República Argentina). 1: Descripciónes sistemáticas. Ameghiniana, 5(No. 9):333-370.

1969. Esporas y granos de polen del Jurásico de Neuquén (Republica Argentina), II. Ameghiniana, 6(No. 2):127-145. 1971. Zur stratigraphischen Verbreitung von Sporen und Pollen im Unter- und Mitteljura des Neuquén-Beckens (Argentinien). Münstersche Forsch. Geol. Paläontol., 20/21:297-321.

1972. Estudio palinologica de un Carbón Calloviano de Neuquén y consideraciones sobre los paleoclimas Jurásicos de la Argentina. Rev. Mus. La Plata, n.s. Secc. Paleont., 6(40): 101-157.

1974. Palinologia estratigráfica del Jurásico de la Sierra de Chacai Có y adyacencias (Cuenca Neuquina, Republica Argentina), II. Ameghiniana, 11(No. 2):135-172.

Volkheimer, W., Caccavari de Filice, M. A., and Sepulveda, E., 1977. Datos palinológicos de la Formación Ortiz (Grupo la Amarga), Cretácico inferior de la Cuenca Neuquina (Republica Argentina). Ameghiniana, 14(No. 1-4):59-74.

Volkheimer, W., and Quattrocchio, M., 1975. Palinología estratigráfica del Titoniano (Formación Vaca Muerta) en el area de Caichigüe (Cuenca Neuquina). Part A: Especies terrestres. Ameghiniana, 12(No. 3):193-241.

Volkheimer, W., and Sepúlveda, E., 1976. Biostratigraphische Bedeutung and mikrofloristische Assoziation von Cyclusphaera psilata n. sp., einer Leitform aus der Unterkreide des Neuquén-Beckens (Argentinien). Neues Jahrb. Geol. Palaontol. Monatsh., 2:97-108.

Weyland, H., and Krieger, W., 1953. Die Sporen und Pollen der Aachener Kreide and ihre Bedeutung fur die Charakterisierung des Mittleren Senons. Palaeontographica, B, 95:6-29.

Wilson, L. R. and Webster, R. M., 1946. Plant microfossils from a Fort Union Coal of Montana. Am. J. Bot., 33:271-278. 


\section{Z. KOTOVA}

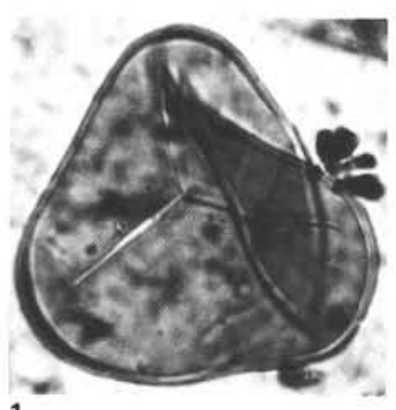

1

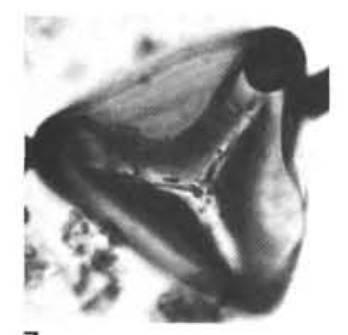

7
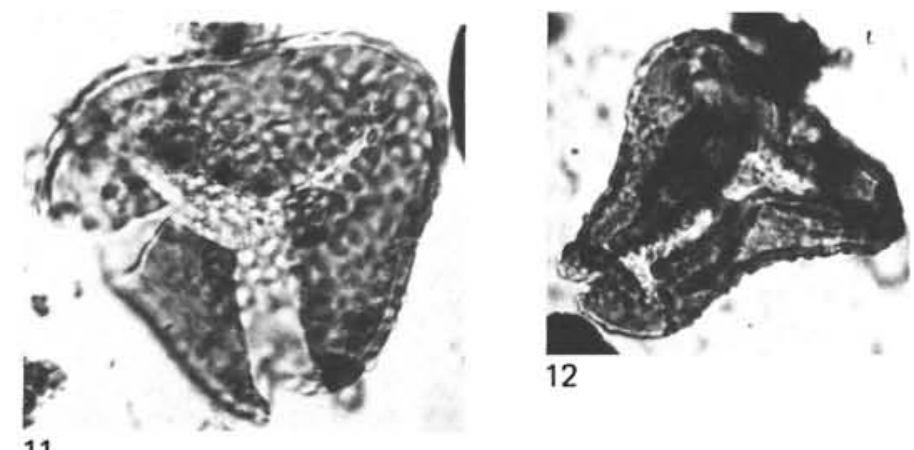

11

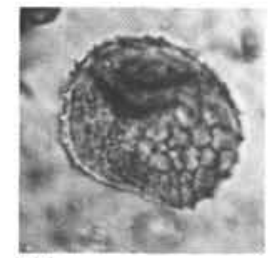

16

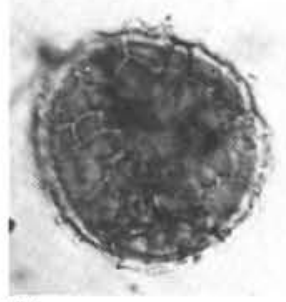

17

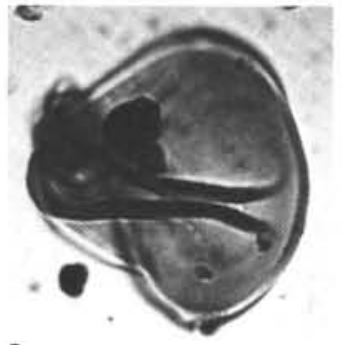

2

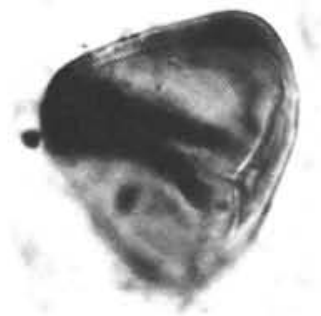

8
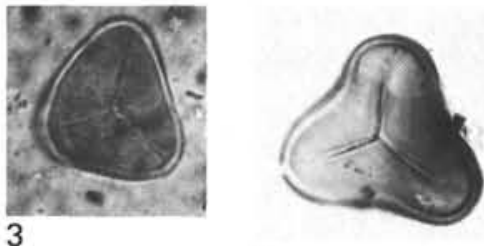

4

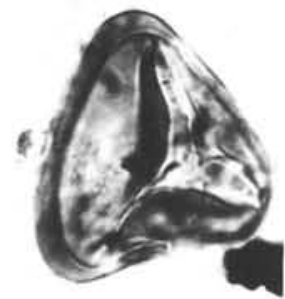

9
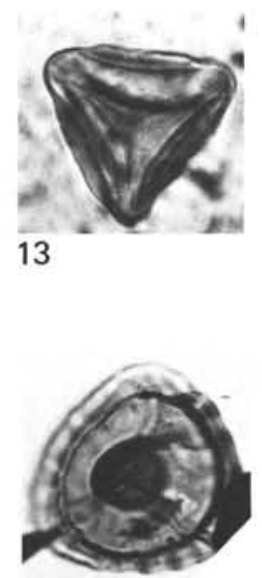

19

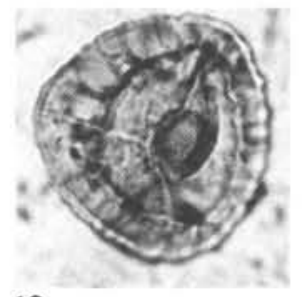

18
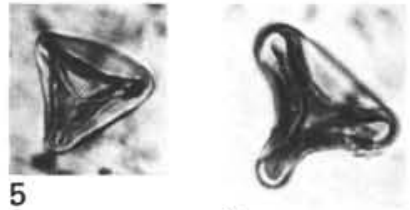

6

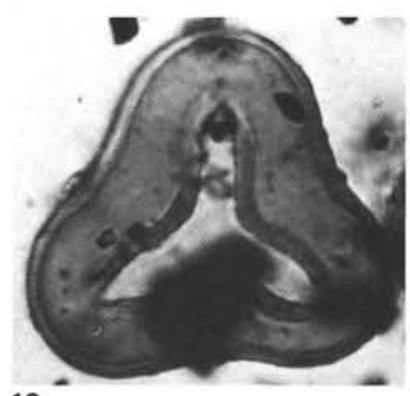

10
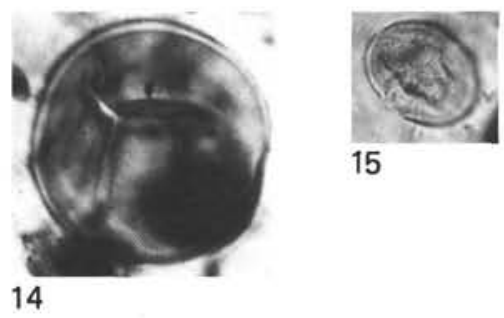

15

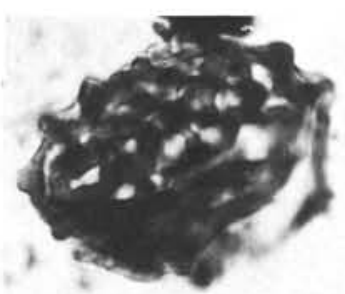

20

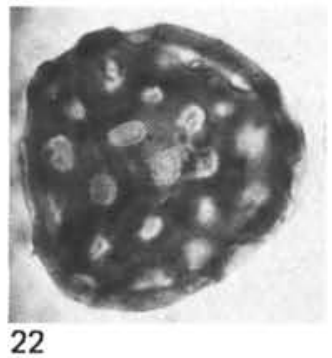

Plate 1. (All specimens magnified $\times 600$.) 1-2. Cyathidites australis Couper (1) Sample 511-57-3, 33-35 cm (2) Sample 511-60-4, 26-28 $\mathrm{cm}$. 3-4. Cyathidites minor Couper (3) Sample 511-70-5, 22-24 cm (4) Sample 511-57-2, 33-35 cm. 5-6. Dictyophyllidites sp. (5) Sample 511-70-1, 22-24 cm (6) Sample 511-69-2, 42-44 cm. 7-9. Matonisporites crassiangulatus (Balme) Dettmann (7) Sample 511-61-2, 62-66 cm (8) Sample 511-70-1, 22-24 cm (9) Sample 511-67-2, 82-84 cm. 10. Concavissimisporites sp. Sample 511-58,CC. 11. Concavissimisporites variverrucatus (Couper) Brenner, Sample 511-61-4, 50-54 cm. 12. Granulatisporites sp., Sample 511-69-2, 42-44 cm. 13. Gleicheniidites senonicus Ross, Sample 511-57-3, 33-35 cm. 14. Todisporites rotundiformis (Mal.) Pocock, Sample 511-57-3, 33-35 cm. 15. Marattisporites scabratus Couper, Sample 511-70-1, 22-24 cm. 16-17. Lycopodiumsporites sp. (16) Sample 511-70-1, 22-24 cm (17) Sample 511-57-2, 33-35 $\mathrm{cm}$. 18-19. Staplinisporites caminus (Balme) Pocock (18) Sample 511-70-1, 22-24 cm (19) Sample 511-61-2, 62-66 cm. 20-21. Ischyosporites marburgensis de Jersey (20) Sample 511-70-5, 22-24 cm (21) Sample 511-70-3, 22-24 cm. 22. Klukisporites lacunus Filatoff, Sample 511-70-5, $22-24 \mathrm{~cm}$. 


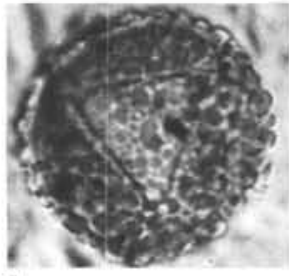

1
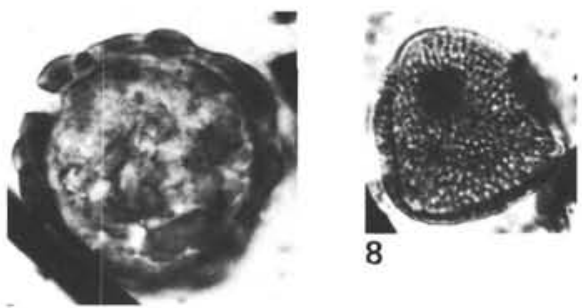

8
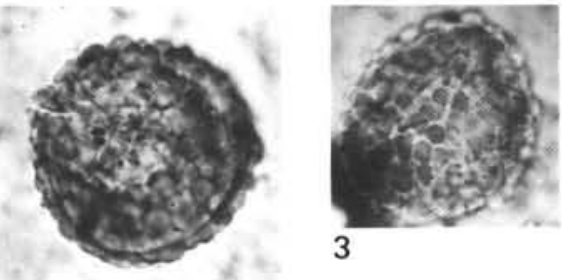

3

2

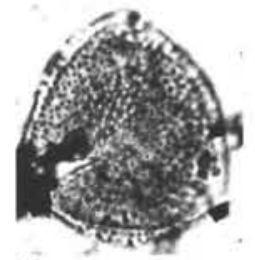

9

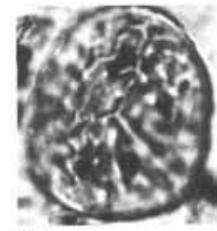

10

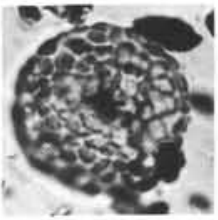

4
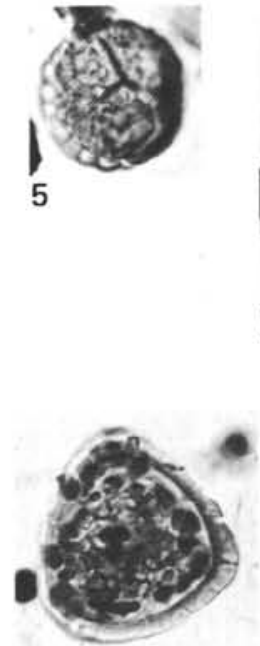

11

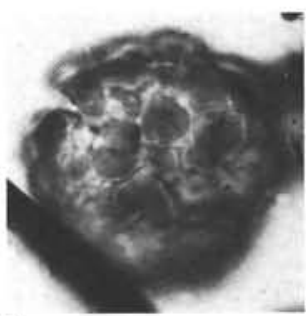

6

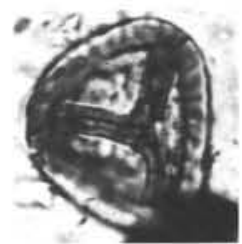

12

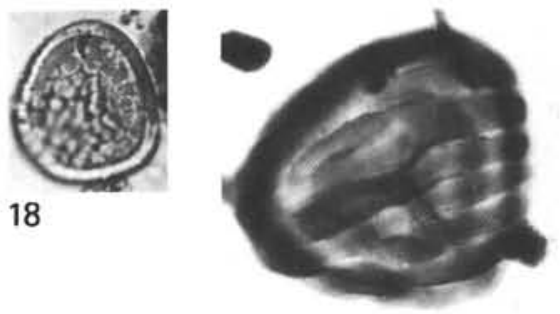

19

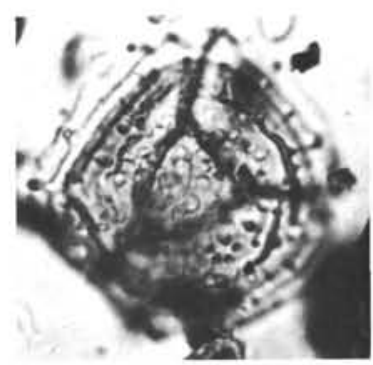

24

20

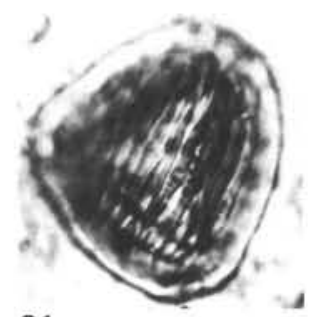

21

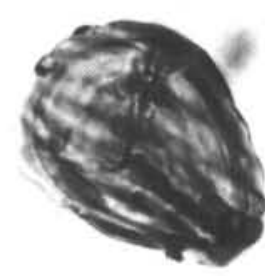

22

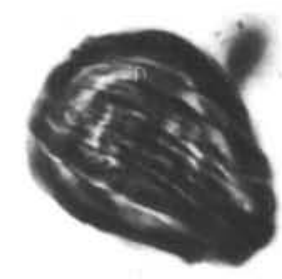

23

Plate 2. (All specimens magnified $\times 600$.) 1-5. Leptolepidites verrucatus Couper (1-3) Sample 511-70-1, 22-24 cm (4) Sample 511-60-2, 26-28 cm (5) Sample 511-70-4, 22-24 cm. 6-7. Leptolepidites macroverrucosus Schulz, Sample 511-69-2, 42-44 cm. 8-9. Foveosporites subtriangularis (Brenner) Döring (8) Sample 511-70-5, 22-24 cm (9) Sample 511-64-1, 30-34 cm. 10. Foveosporites moretonensis de Jersey, Sample 511-57-3, 33-35 cm. 11-15. Antulsporites saevus (Balme) Archangelsky and Gamerro (11-12) Sample 511-70-5, 22-24 cm (13-15) Sample 511-64-1, 30-34 cm. 16-18. Antulsporites varigranulatus (Levet-Carette) Reiser and Williams (16) Sample 511-70-1, 22-24 cm (17) Sample 511-62-5, 40-44 cm (18) Sample 511-61-2, 62-66 cm. 19-20. Contignisporites fornicatus Dettmann, Sample 511-63-1, 130-134 cm. 21-23. Contignisporites cooksonii (Balme) Dettmann (21) Sample 511-61-3, 61-65 cm (22-23) Sample 511-60-4, 26-28 cm. 24. Cyclocrystella sp. Sample 511-63-1, 130-134 cm. 


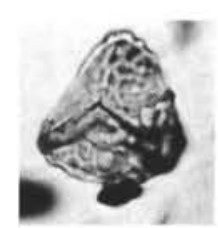

1

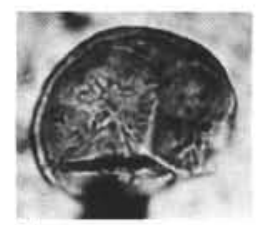

7

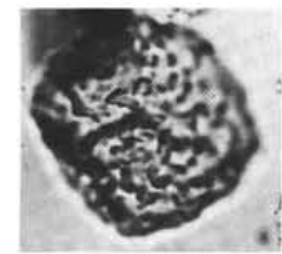

13

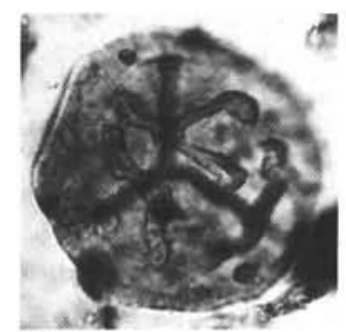

18

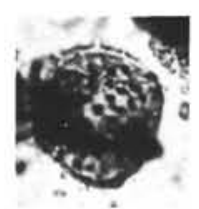

24

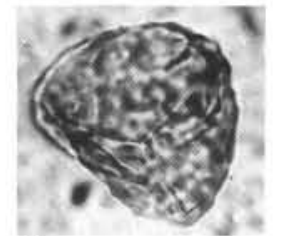

2

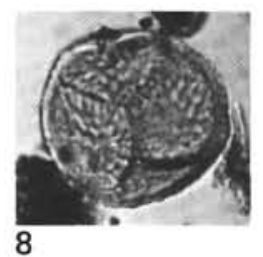

8

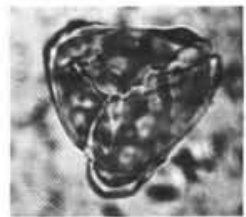

3

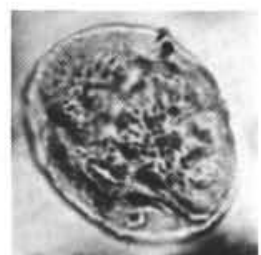

9

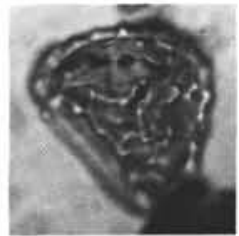

4

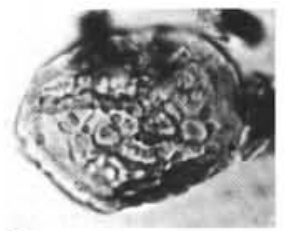

10

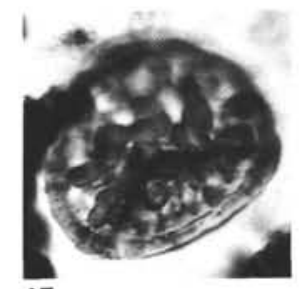

15

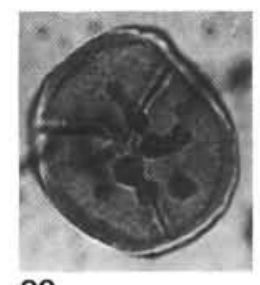

20

16
19
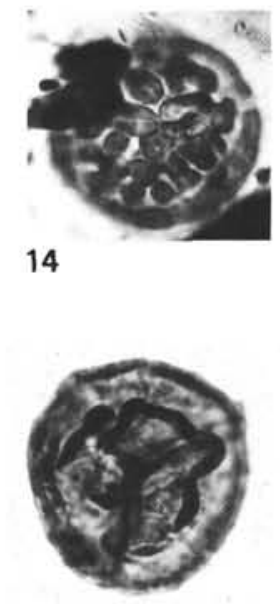

14

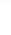

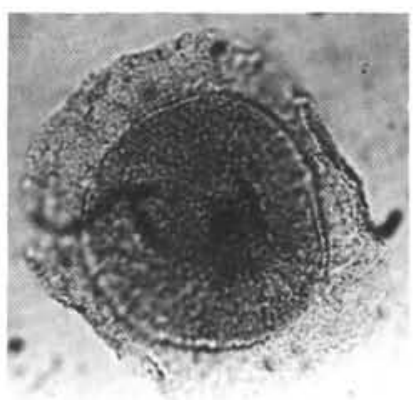

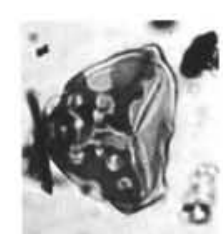

5

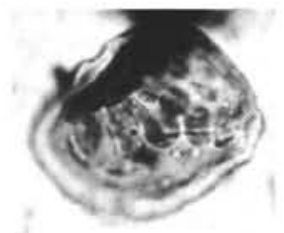

11
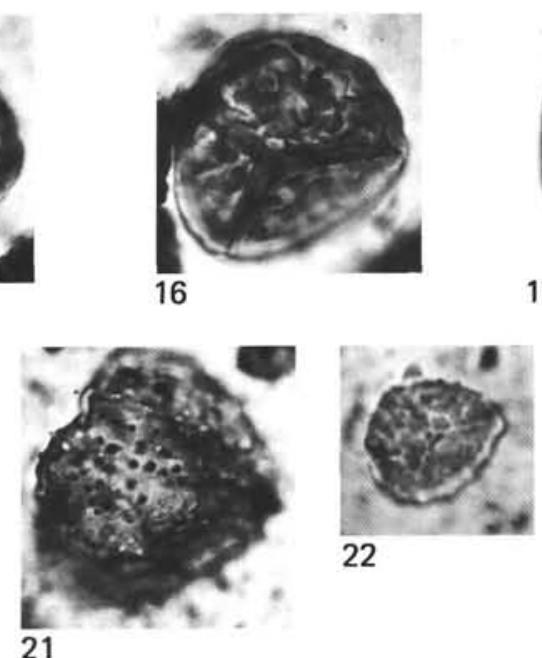

22
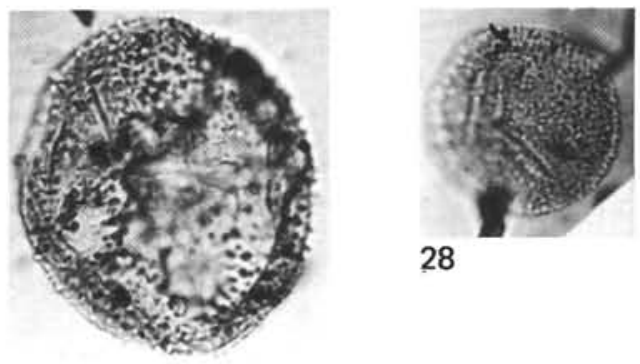

28

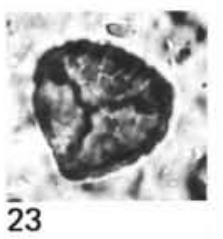

25

Plate 3. (All specimens magnified $\times 600$.) 1-6. Ischyosporites volkheimeri Filatoff (1) Sample 511-70-4, 22-24 cm (2-3) Sample 511-70-1, 22-24 cm (4-5) Sample 511-63,CC (6) Sample 511-61-5, 36-40 cm. 7-9. Nevesisporites sp. (7-8) Sample 511-70-1, 22-24 cm (9) Sample 511-59-4, 133-135 $\mathrm{cm}$. 10-11. Interulobites triangularis (Brenner) Paden et al. (10) Sample 511-60-4, 26-28 cm (11) Sample 511-64-1, 30-34 cm. 12-13, Interulobites algoensis Scott (12) Sample 511-70-1, 22-24 cm (13) Sample 511-59-4, 133-135 cm. 14-17. Interulobites sinuosus Scott (14) Sample 511-64-1, 30-34 cm (15-17) Sample 511-63-1, 130-134 cm. 18-20. Interulobites sp. (18) Sample 511-63-1, 130-134 cm; (19) Sample 511-64-1, 30-34 cm (20) Sample 511-60-4, 26-28 cm. 21. Anapiculatisporites dawsonensis Reiser and Williams, Sample 511-63-1, 130-134 cm. 22-23. Converrucosisporites utriculosus (Krasn.) Pocock, Sample 511-70-5, 22-24 cm. 24. Neoraistrickia sp., Sample 511-59,CC. 25-26. Dictyotosporites complex Cookson and Dettmann (25) Sample 511-70-5, 22-24 cm (26) Sample 511-61-3, 61-65 cm. 27. Baculatisporites comaumensis (Cookson) Potonié, Sample 511-67-5, 82-84 cm. 28. Osmundacidites wellmanii Couper, Sample 511-70-4, 22-24 cm. 

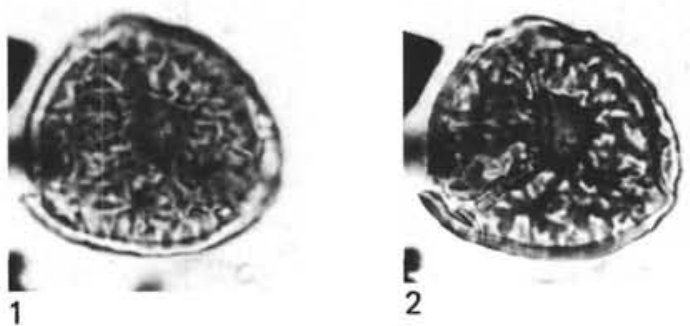

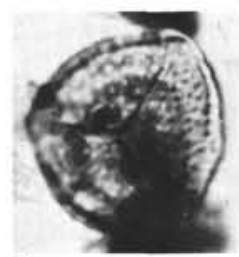

3

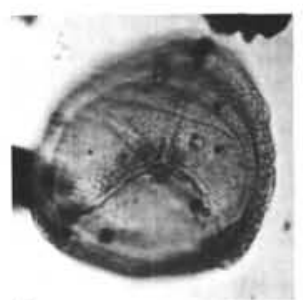

4

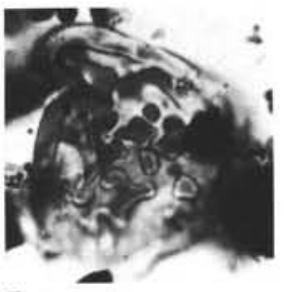

5

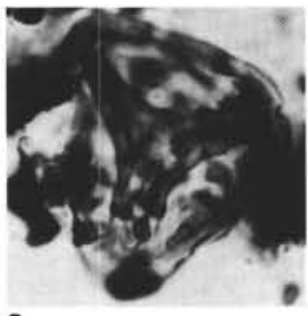

6

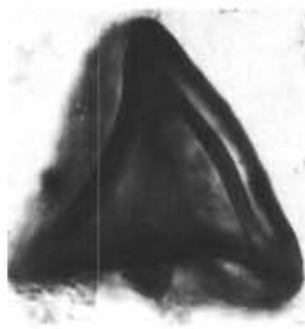

11

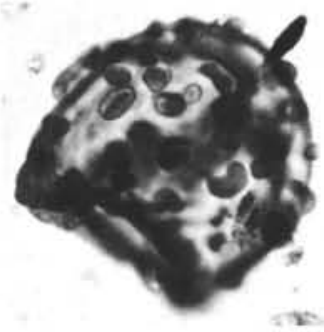

7

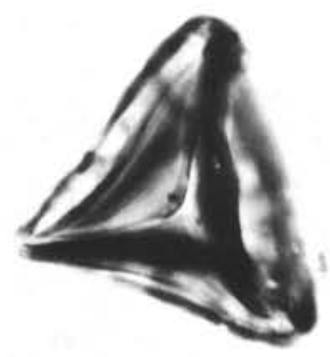

12

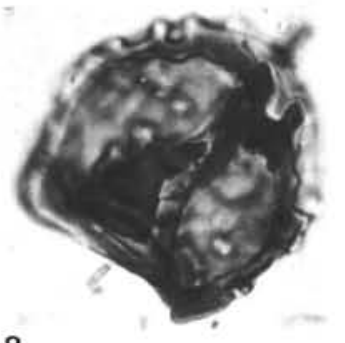

8

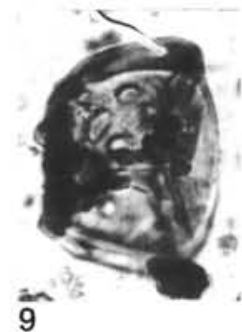

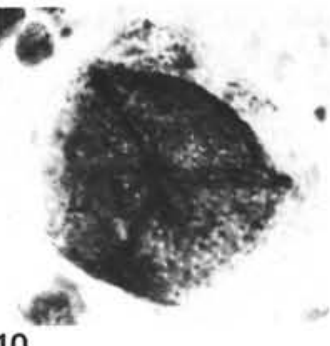

10

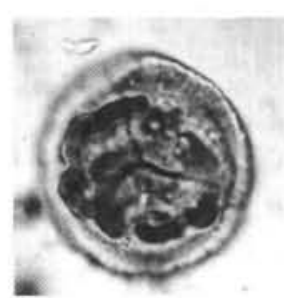

13
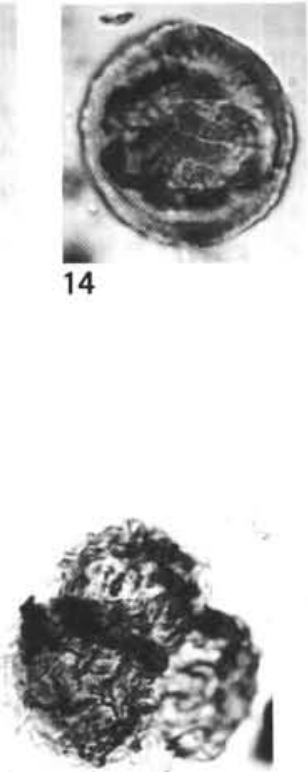

20
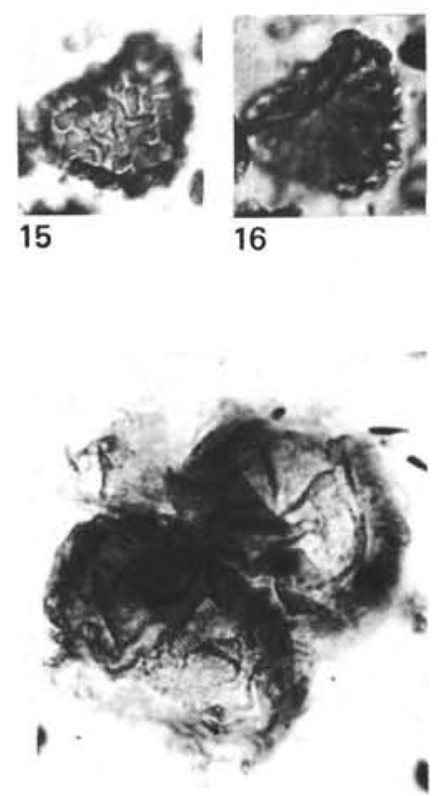

21

Plate 4. (All specimens magnified $\times 600$.) 1-2. Coronatispora valdensis (Couper) Dettmann, Sample 511-58-1, 44-46 cm. 3. Coronatispora perforata Dettmann, Sample 511-60-2, 26-28 cm. 4. Densoisporites velatus Weyland and Krieger, Sample 511-58-2, 142-144 cm. 5-9. Polypodiaceoisporites elegans Archangelsky and Gamerro (5-6) Sample 511-60-3, 26-28 cm (7-8) Sample 511-61,CC (9) Sample 511-62-4, 120-124 $\mathrm{cm}$. 10. Sestrosporites pseudoalveolatus (Couper) Dettmann. Sample 511-57-3, 33-35 cm. 11-12. Distaltriangulisporites pelliculus Scott, Sample 511-62-1, 38-42 cm. 13-14. Taurocusporites segmentatus Stover, Sample 511-57-5, 33-35 cm. 15-17. Trilites sp. 1 (15-16) Sample $511-62-3,35-39 \mathrm{~cm}$ (17) Sample 511-60-2, 26-28 cm. 18. Patellasporites sp., Sample 511-62-5, $40-44 \mathrm{~cm}$. 19-21. Crybelosporites berberioides Burger (19-20) Sample 511-63-1, 130-134 cm (21) Sample 511-70-4, 22-24 cm. 


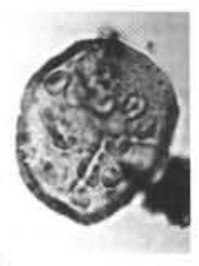

1

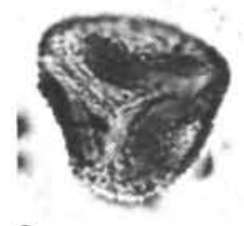

6

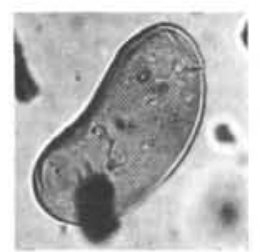

11
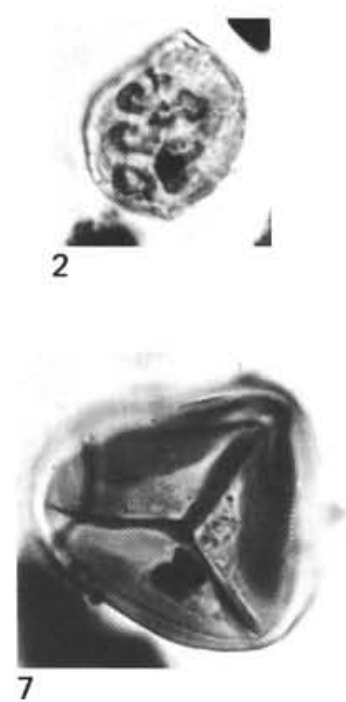

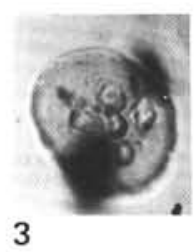

3

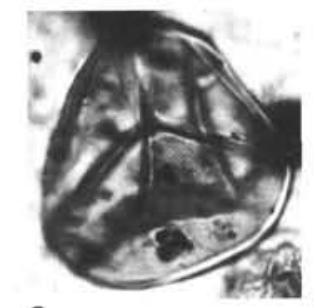

8

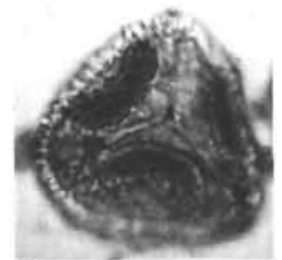

4

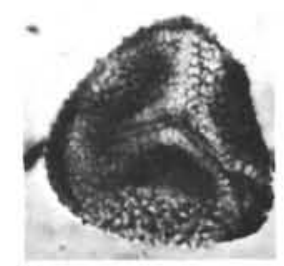

5

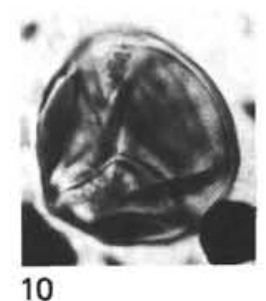

10
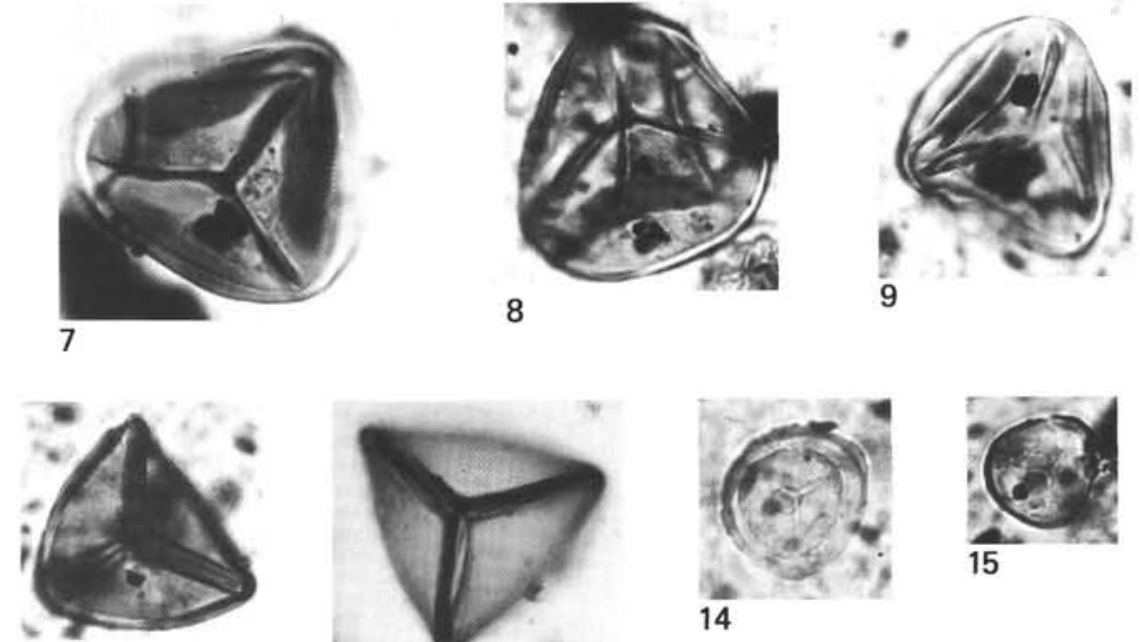

12

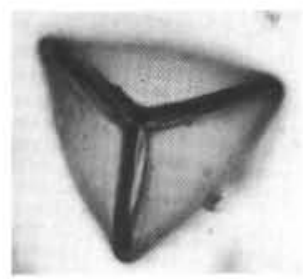

13
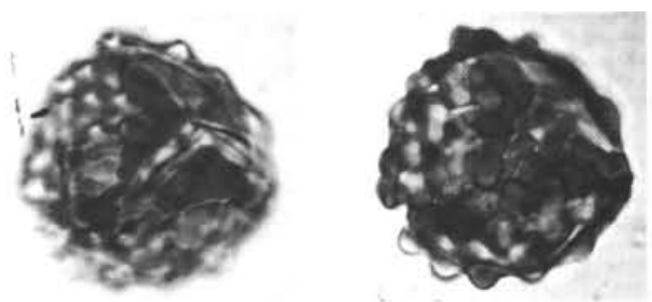

18

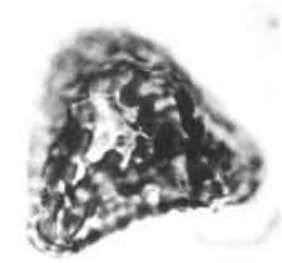

19
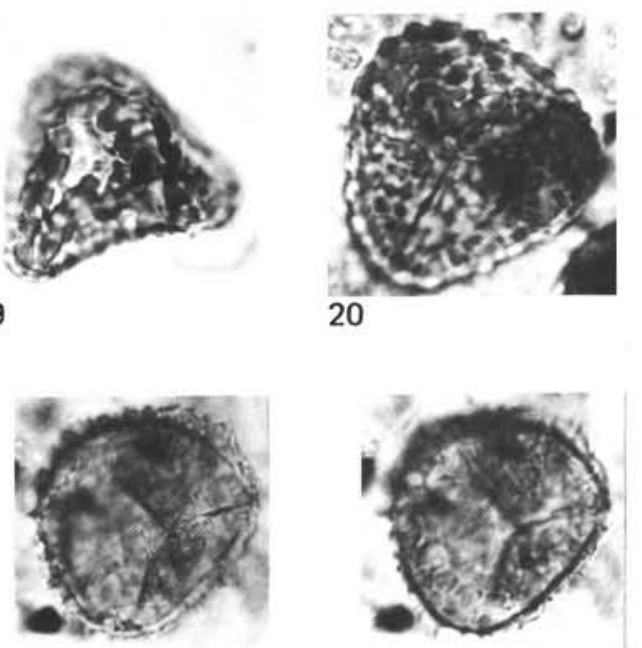

23

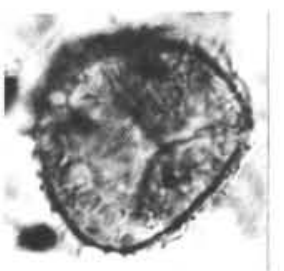

24

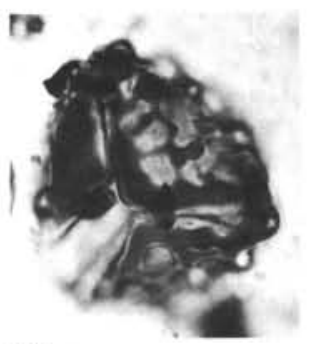

16

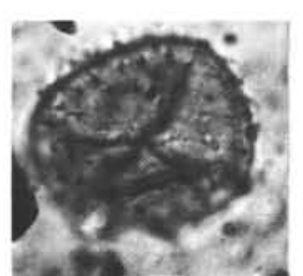

21

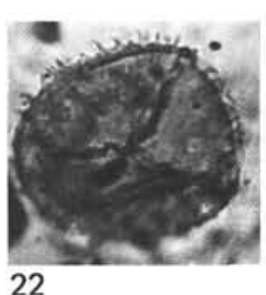

22

Plate 5. (All specimens magnified $\times 600$.) 1-3. Kuylisporites lunaris Cookson and Dettmann (1) Sample 511-60-3, 26-28 cm (2) Sample 511-62-3, 35-39 cm (3) Sample 511-58,CC. 4-6. Ceratosporites distalgranulatus (Couper) Kemp, Sample 511-57-5, 33-35 cm. 7-10. Gleicheniidites spp. (7) Sample 511-57-5, 33-35 cm (8-9) Sample 511-57-3, 33-35 cm (10) Sample 511-56-5, 58-60 cm. 11. Laevigatosporites ovatus Wilson and Webster, Sample 511-58-1, 44-46 cm. 12-13. Biretisporites sp. (12) Sample 511-57-3, 33-35 cm (13) Sample 511-58-2, 142-144 cm. 14. Cingutriletes clavus (Balme) Dettmann, Sample 511-57-3, 33-35 cm. 15. Stereisporites antiquasporites (Wilson and Webster) Dettmann, Sample 511-57-1, 33-35 cm. 16-18. Ischyosporites sp. 1 (16) Sample 511-57-4, 33-35 cm. (17-18) Sample 511-58-2, 142-144 cm. 19-20. Ischyosporites sp. 2 (19) Sample 511-57-4, 33-35 cm (20) Sample 511-62-1, 38-42 cm. 21-24. Perotrilites linearis (Cookson and Dettmann) Evans, Sample $511-57-3,33-35 \mathrm{~cm}$. 

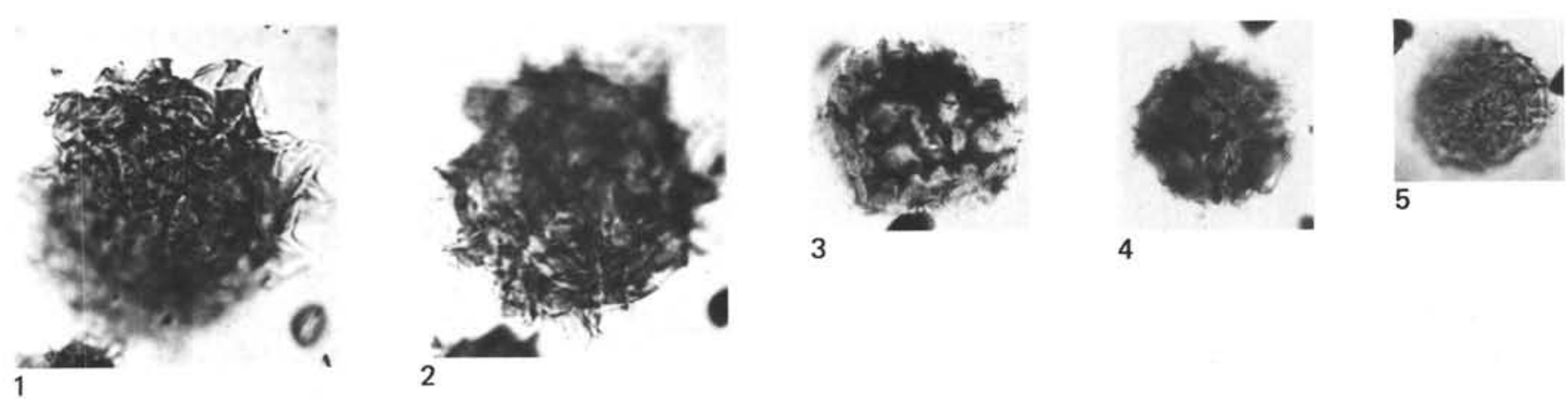

\section{3}

4
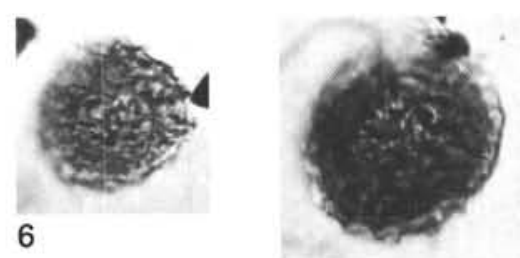

7

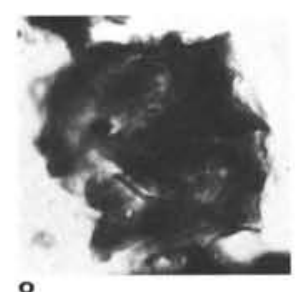

8
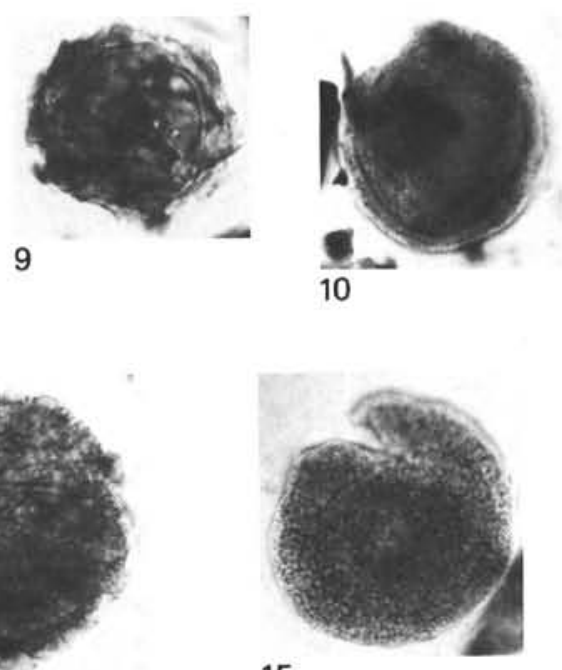

15
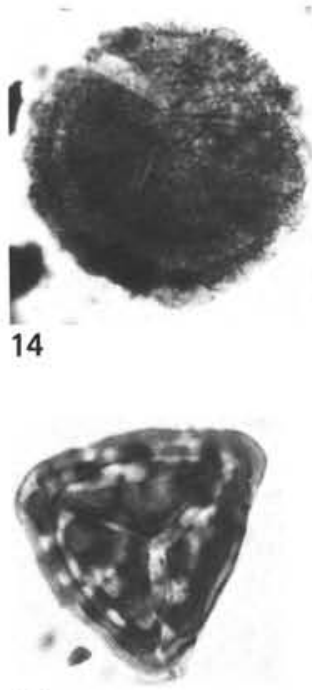

19

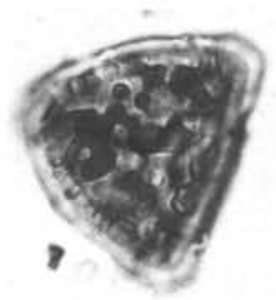

18
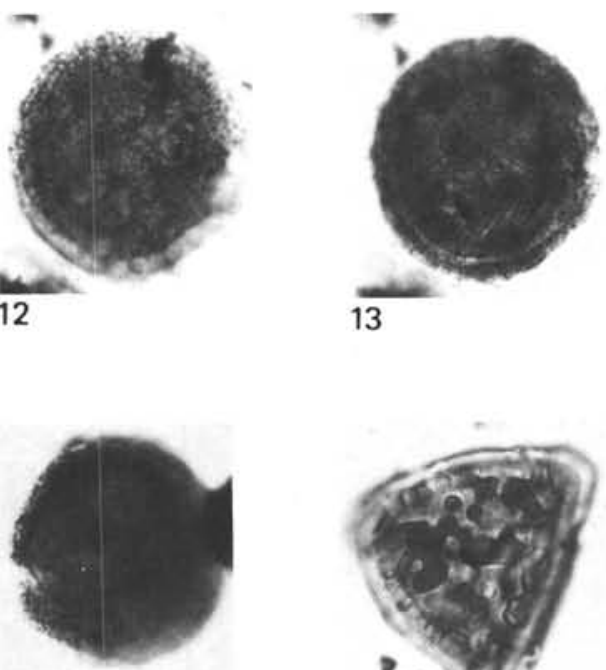

17

Plate 6. (All specimens magnified $\times 600$.) 1-9. Crybelosporites aff. striatus (Cookson and Dettmann) Dettmann $(1,2,5,6)$ Sample 511-58-2, 142$144 \mathrm{~cm}(3,4,7,8)$ Sample 511-57-3, 33-35 cm (9) Sample 511-57-6, 33-35 cm. 10-17. Crybelosporites sp. 1 (10-11) Sample 511-57-6, 33-35 cm (12-14) Sample 511-57-3, 33-35 cm (15) Sample 511-58-3, 53-55 cm (16-17) Sample 511-57-2, 33-35 cm. 18-21. Muricingulisporis annulatus Archangelsky and Gamerro (18-19) Sample 511-57-5, 33-35 cm (20-21) Sample 511-57-3, 33-35 cm. 

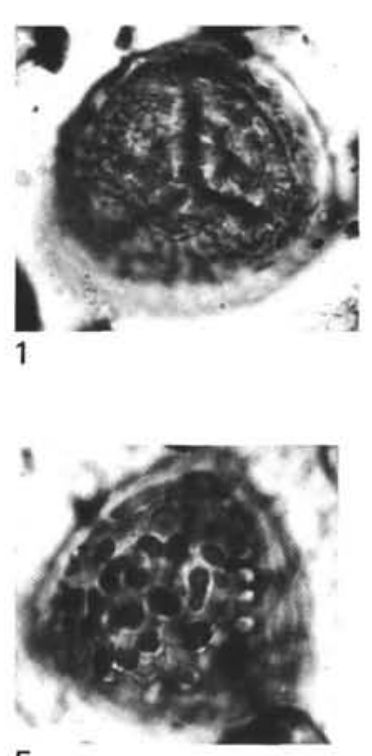

5

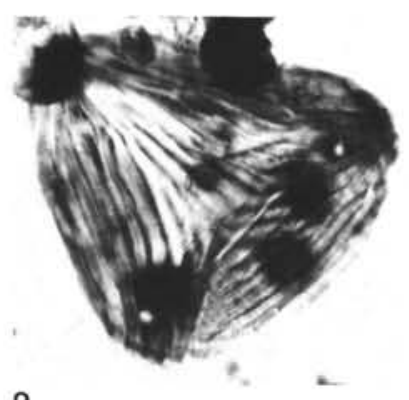

9

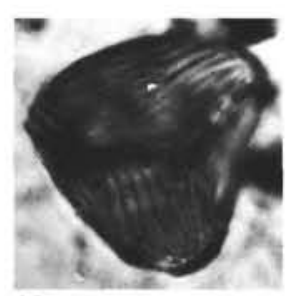

13

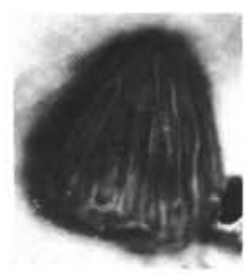

18
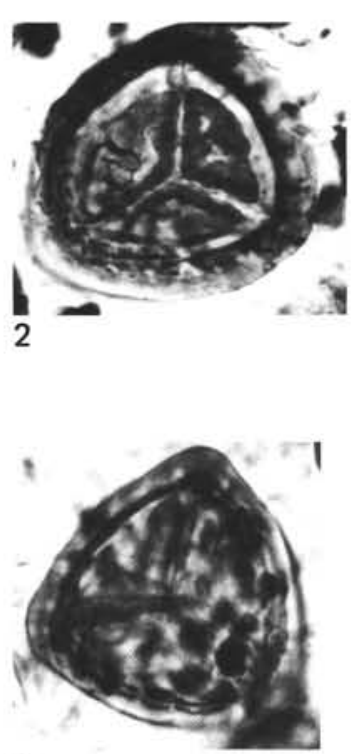

6

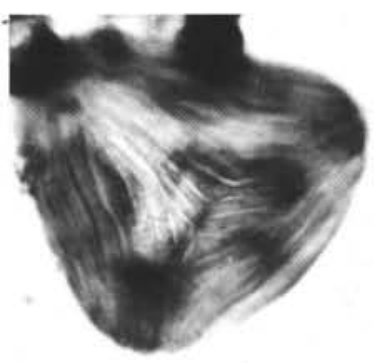

10

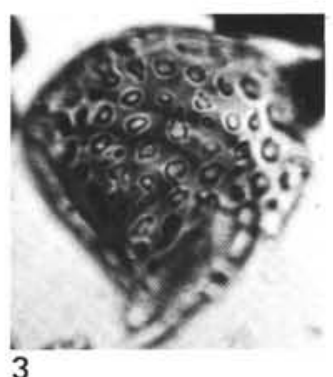

3

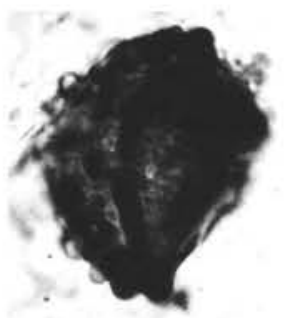

7

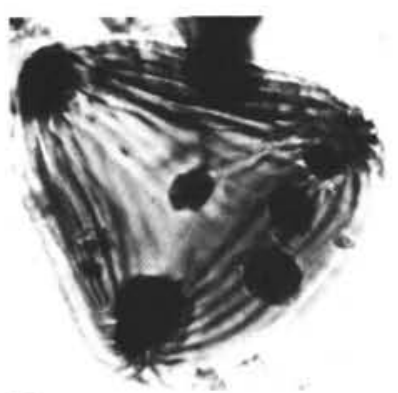

11
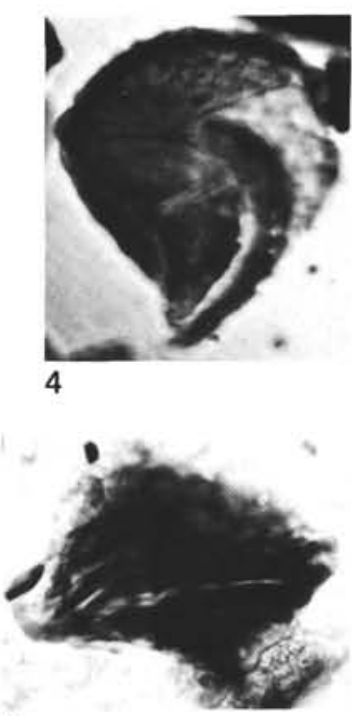

8

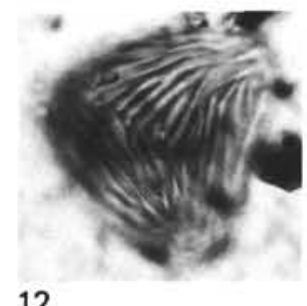

12

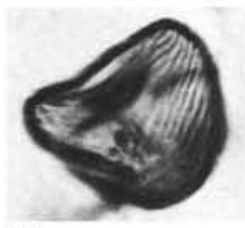

16

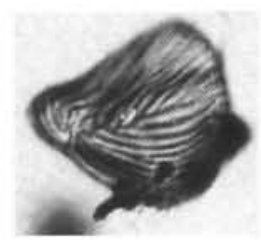

17

14

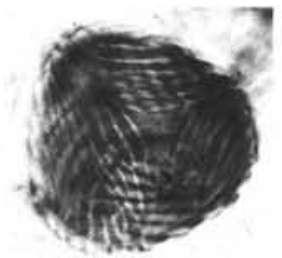

19
15
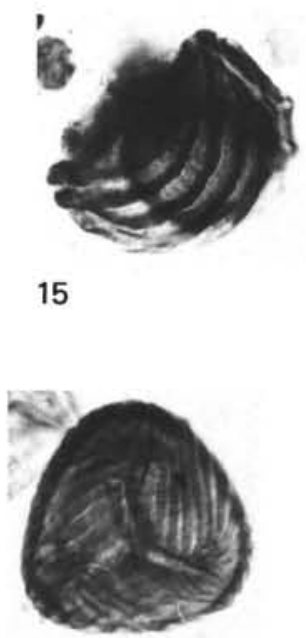

20

Plate 7. (All specimens magnified $\times 600$.) 1-2. Cyatheacidites tectifera Archangelsky and Gamerro, Sample 511-57-6, 33-35 cm. 3-4. Cyatheacidites sp. 1, Sample 511-58-2, 142-144 cm. 5-7. Cyatheacidites sp. 2 (5-6) Sample 511-58-2, 142-144 cm (7) Sample 511-56-5, 58-60 $\mathrm{cm}$. 8. Appendicisporites sp., Sample 511-56-5, 58-60 cm. 9-11. Cicatricosisporites ludbrooki Dettmann (Sample 511-61-4, 50-54 cm. 1214. Cicatricosisporites australiensis (Cookson) Potonié (12-13) Sample 511-57-3, 33-35 cm (14) Sample 511-58-2, 142-144 cm. 15. Cicatricosisporites hughesi Dettmann, Sample 511-61-3, 61-65. 16-18. Cicatricosisporites hallei Delcourt and Sprumont, Sample 511-57-4, 33-35 cm. 19-20. Cicatricosisporites proxiradiatus Kemp, Sample 511-57-3, 33-35 cm. 


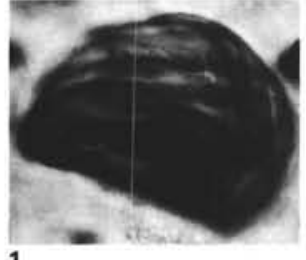

1

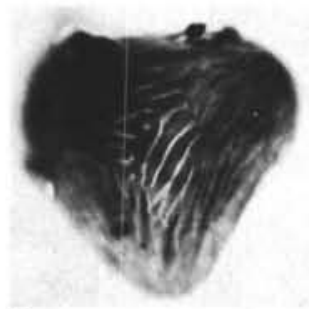

6

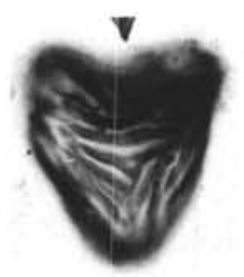

11

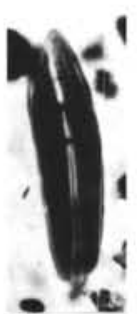

17

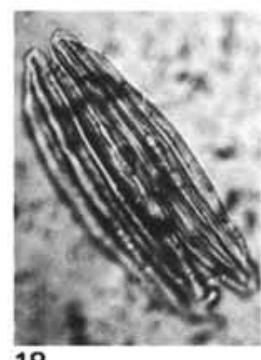

18
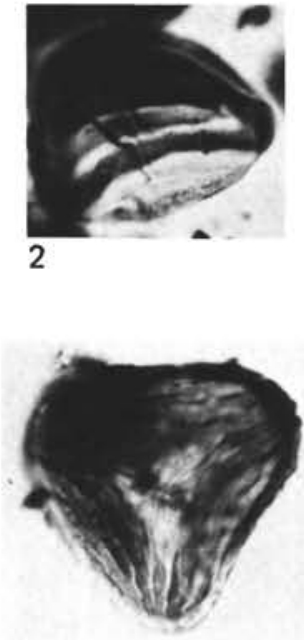

7

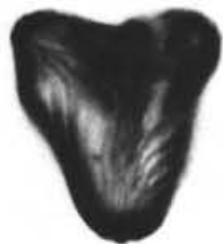

12

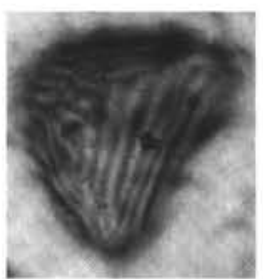

13

3

8
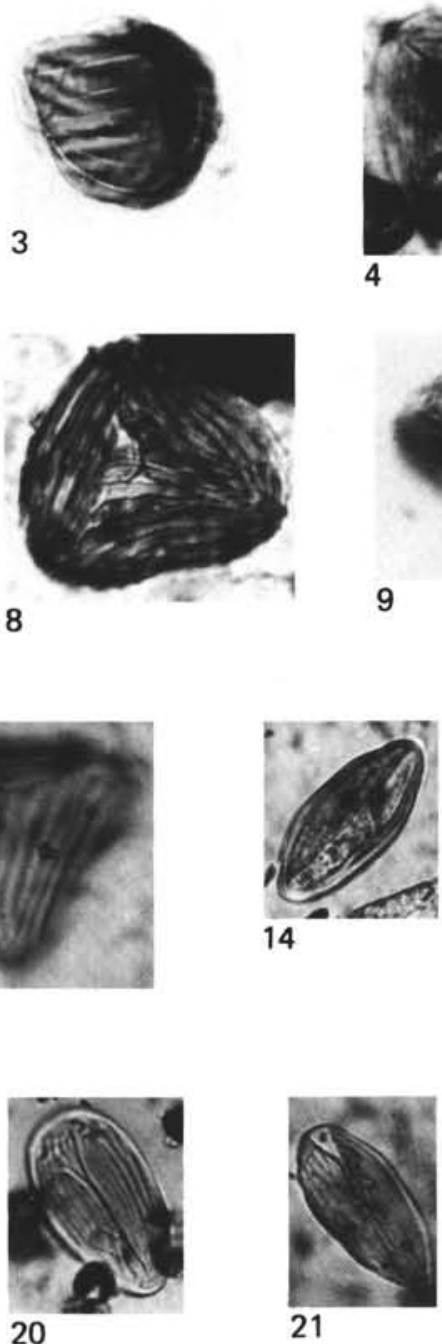

21
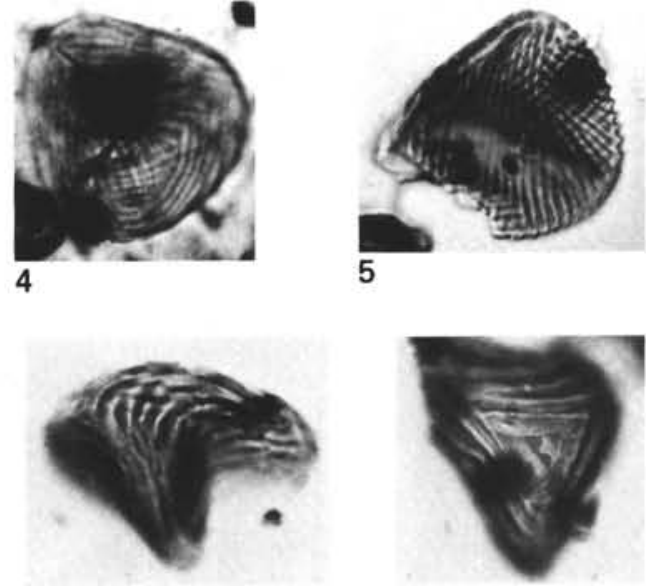

9

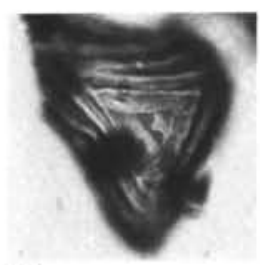

10

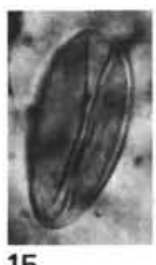

15

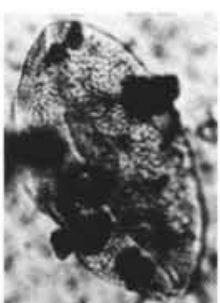

16
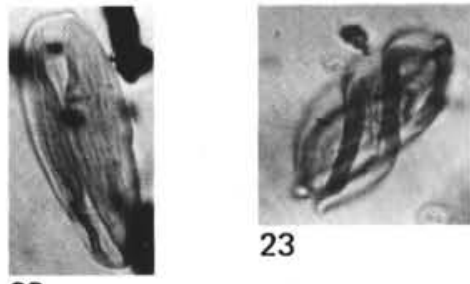

23

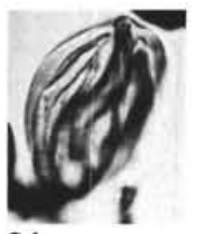

24

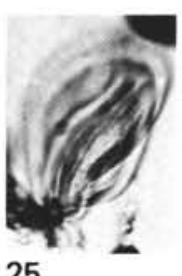

19

Plate 8. (All specimens magnified $\times 600$.) 1-2. Cicatricosisporites $\mathrm{sp}$. (1) Sample 511-60-4, 26-28 cm (2) Sample 511-59,CC. 3. Cicatricosisporites sp. 4, Sample 511-57-6, 33-35 cm. 4-5. Cicatricosisporites sp. 2 (4) Sample 511-57-3, 33-35 cm (5) Sample 511-57-4, 33-35 cm. 6-9. Cicatricosisporites sp. $3(6,7,9)$ Sample 511-57-2, 33-35 cm (8) Sample 511-57-3, 33-35 cm. 10-13. Cicatricosisporites sp. 5 (10) Sample 511-57-4, 33-35 cm 11-12. Sample 511-57-6, 33-35 cm (13) Sample 511-57-3, 33-35 cm. 14-16. Monosulcites spp. (14) Sample 511-69-2, 42-44 cm; (15) Sample 511-59,CC (16) Sample 511-60-2, 26-28 cm. 17-19. Ephedripites sp. 2 (17) Sample 511-70-5, 22-24 cm (18-19) Sample 511-70-1, 22-24 cm. 20-22. Ephedripites sp. 3 (20) Sample 511-61-3, 61-65 cm (21) Sample 511-63-1, 130-134 cm. 23-25. Ephedripites sp. 1 (23) Sample 511-61,CC (24-25) Sample 511-61-3, 61-65 cm. 


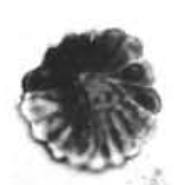

1

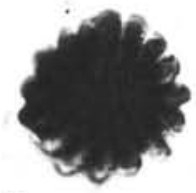

2

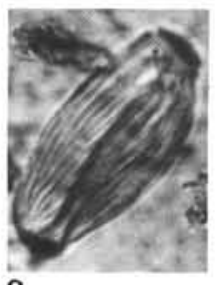

9

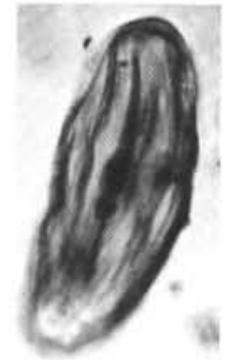

10

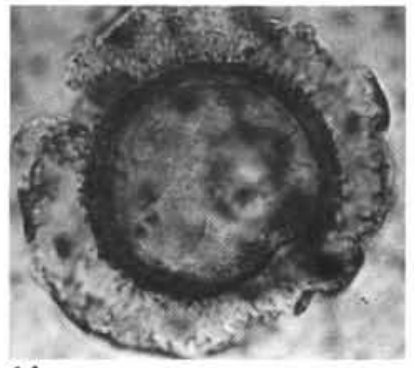

14

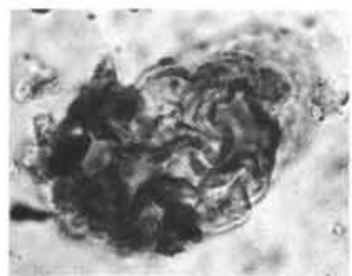

18

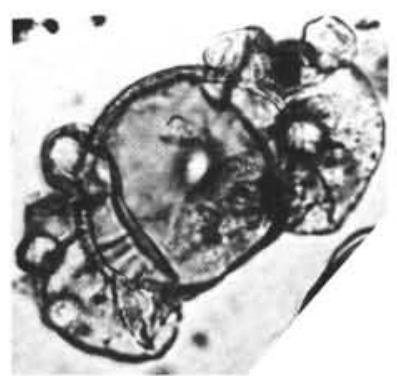

23
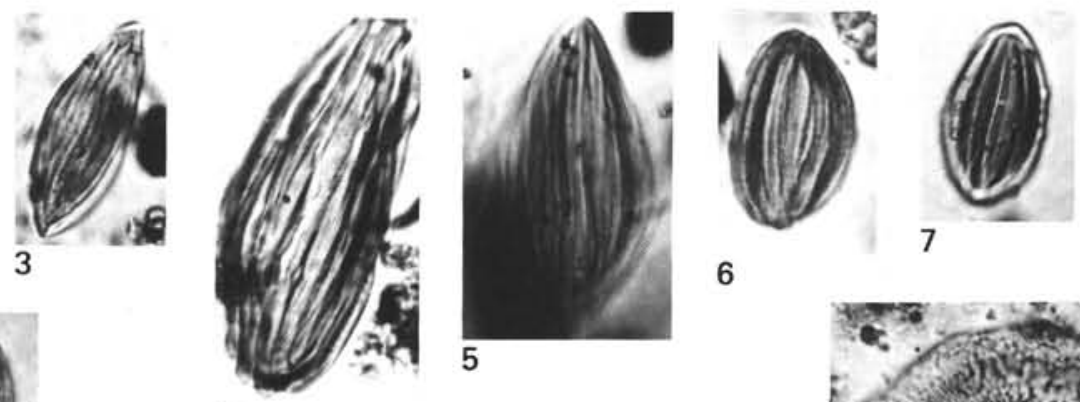

6

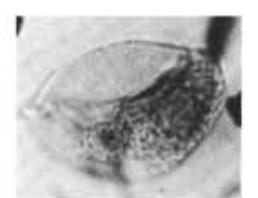

12

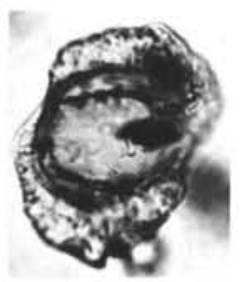

16

15

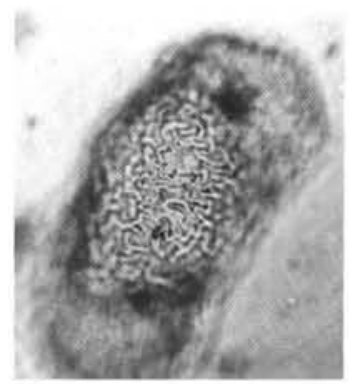

19
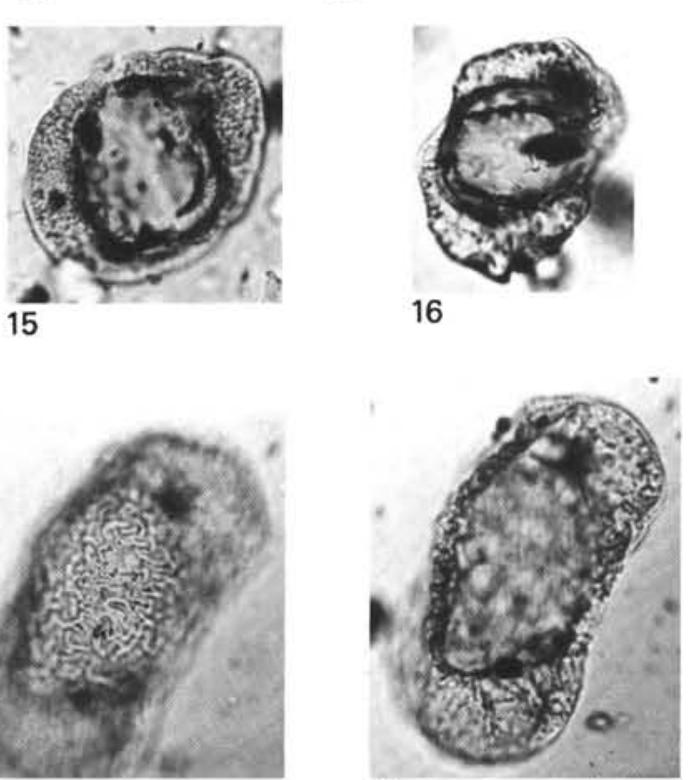

20

13

17

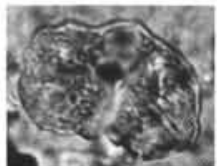

21

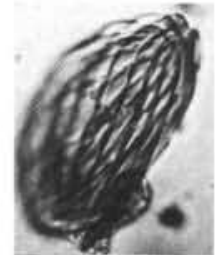

8
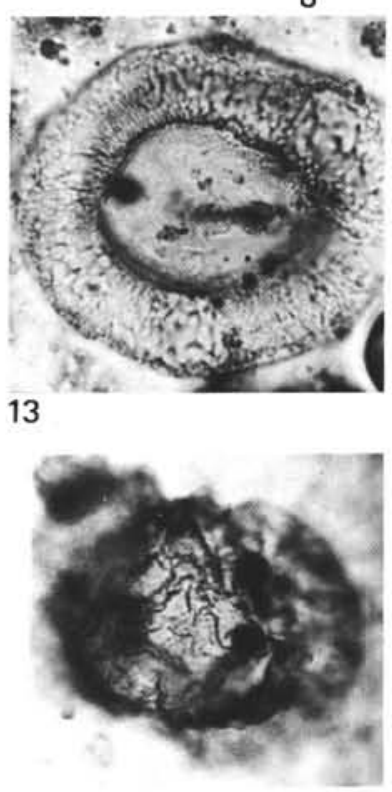

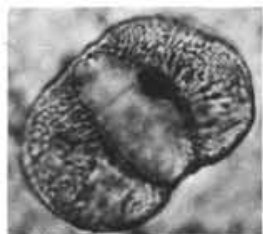

22

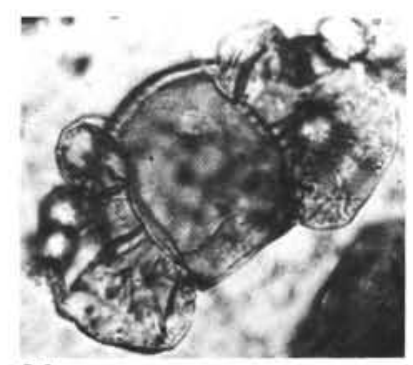

24

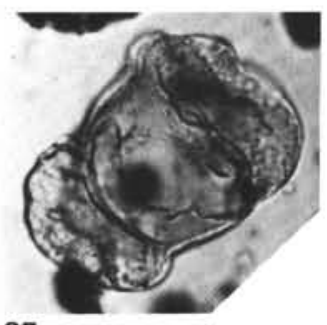

25

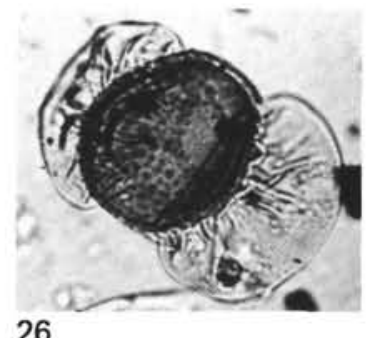

26

Plate 9. (All specimens magnified $\times 600$ ) $\quad$ 1-2. Ephedripites sp. 5, Sample 511-57-5, 33-35 cm. 3-8. Ephedripites spp. (3) Sample 511-70-1, 22-24 cm (4) Sample 511-62-2, 54-58 cm (5) Sample 511-58-2, 142-144 cm (6) Sample 511-70-2, 22-24 cm (7) Sample 511-58-1, 44-46 cm (8) Sample 511-60-3, 26-28 cm. 9-10. Steevesipollenites sp. (9) Sample 511-62-1, 38-42 cm (10) Sample 511-58-2, 142-144 cm. 11-12. Monosaccites sp. 2, Sample 511-57-2, 33-35 cm. 13-14. Monosaccites sp. 1 (13) Sample 511-70-5, 22-24 cm (14) Sample 511-62-2, 54-58 cm. 15-16. Sulcosaccispora sp. (15) Sample 511-69-2, 42-44 cm; (16) Sample 511-70-4, 22-24 cm. 17-20. Rugubivesiculites sp. (17) Sample 511-70-5, 22-24 cm (18) Sample 511-70-1, 22-24 cm (19-20) Sample 511-58-2, 142-144 cm. 21-22. Vitreisporites pallidus (Reissinger) Nilsson (21) Sample 511-70-5, 22-24 cm (22) Sample 511-69-2, 42-44 cm. 23-26. Bisacado sp. A (23-24) Sample 511-57-3, 33-35 cm (25-26) Sample 511-58-1, 44-46 cm. 


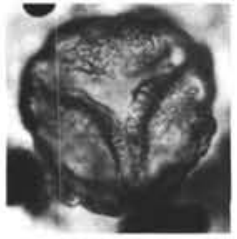

1

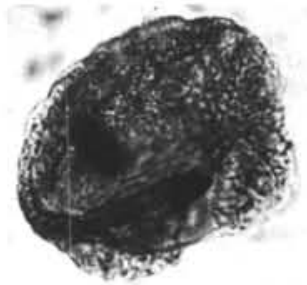

6

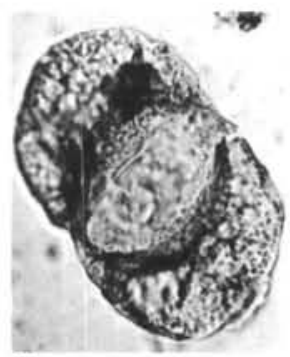

11

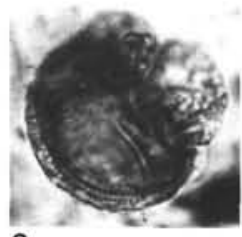

2

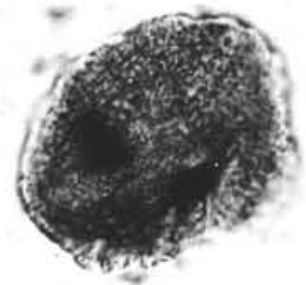

7

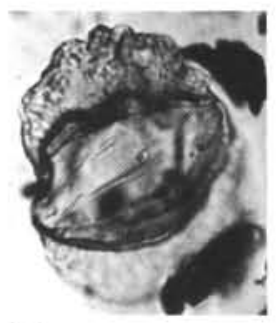

12
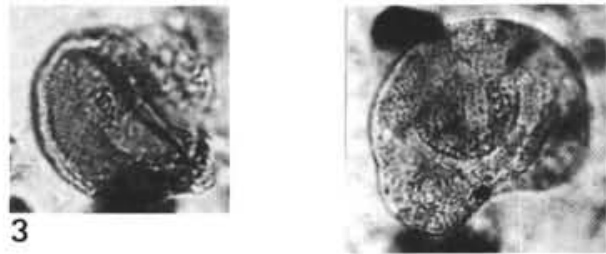

4

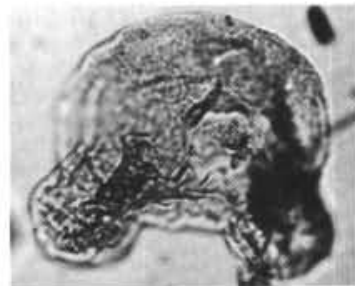

5
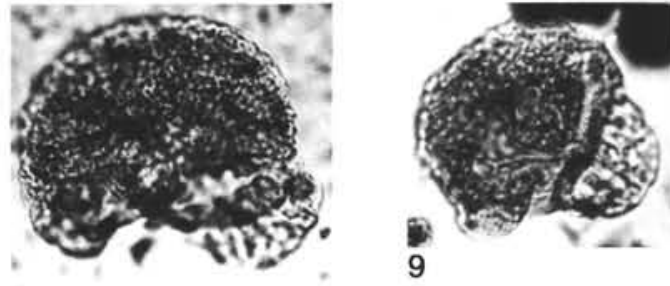

8

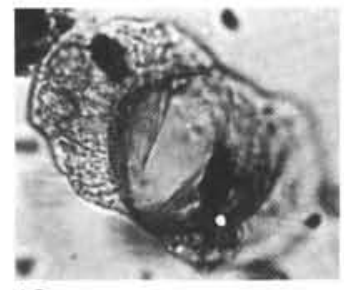

13

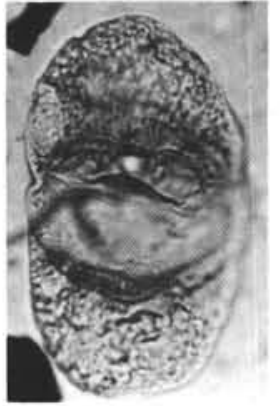

10

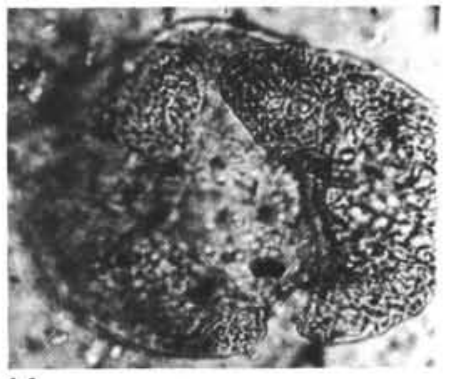

14

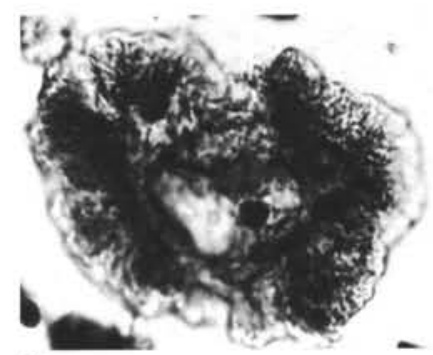

18
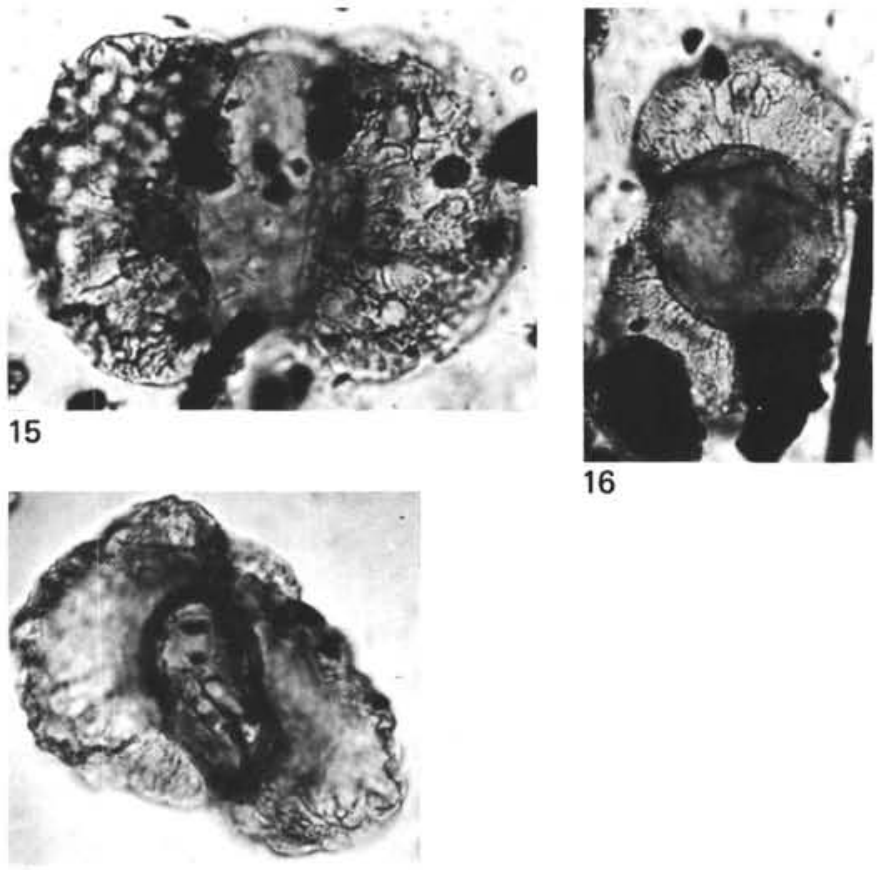

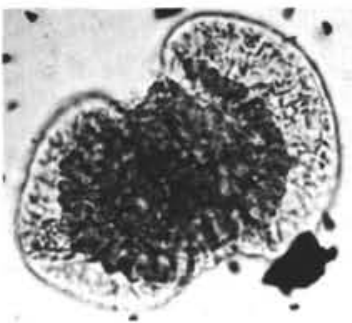

17

19

Plate 10. (All specimens magnified $\times 600$.) 1. Trisaccites sp., Sample 511-63-1, 130-134 cm. 2-4. Microcachryidites antarcticus Cookson (2) Sample 511-66-1, 28-30 cm (3) Sample 511-59,CC (4) Sample 511-57-1, 33-35 cm. 5. Microcachryidites sp., Sample 511-70-4, 22-24 cm. 6-9. Podosporites sp. (6-7) Sample 511-70-5, 22-24 cm (8) Sample 511-64-1, 30-34 cm (9) Sample 511-70-4, 22-24 cm. 10-11. Alisporites lowoodensis de Jersey, Sample 511-69-5, 42-44 cm. 12. Alisporites similis (Balme) Dettmann, Sample 511-70-2, 22-24 cm. 13. Alisporites sp., Sample 511-70-5, 22-24 cm. 14-15. Alisporites grandis (Cookson) Dettmann (14) Sample 511-56-5, 58-60 cm (15) Sample 511-69-2, 42-44 cm. 16-17. Podocarpidites sp. (16) Sample 511-70-3, 22-24 cm (17) Sample 511-58-2, 142-144 cm. 18-19. Disaccites (18) Sample 511-69-2, $42-44 \mathrm{~cm}$ (19) Sample 511-70-4, 22-24 cm. 


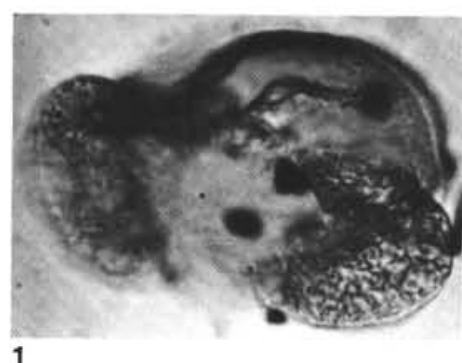

1

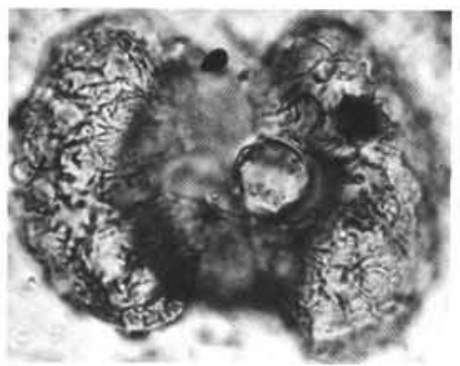

5
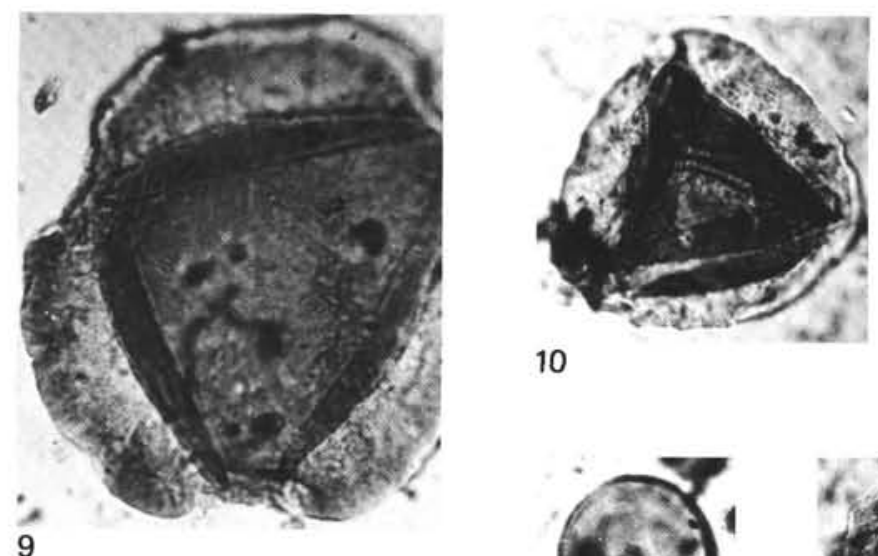

10

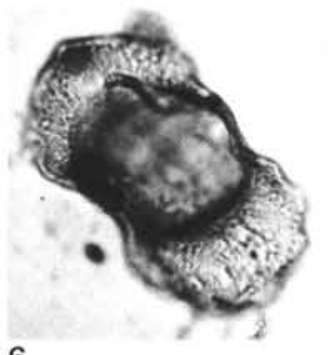

6

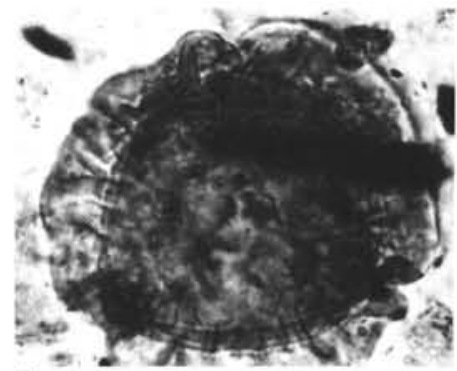

7

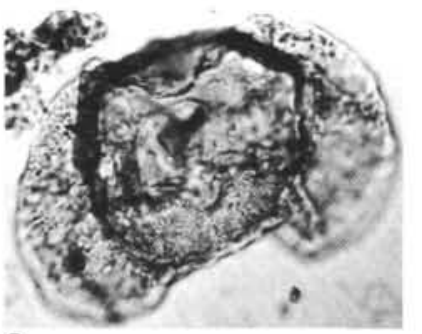

3

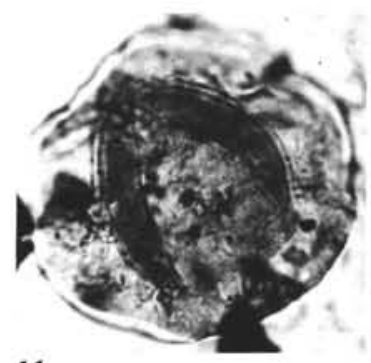

11

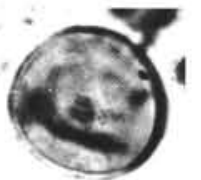

13

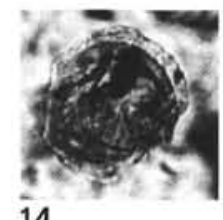

14
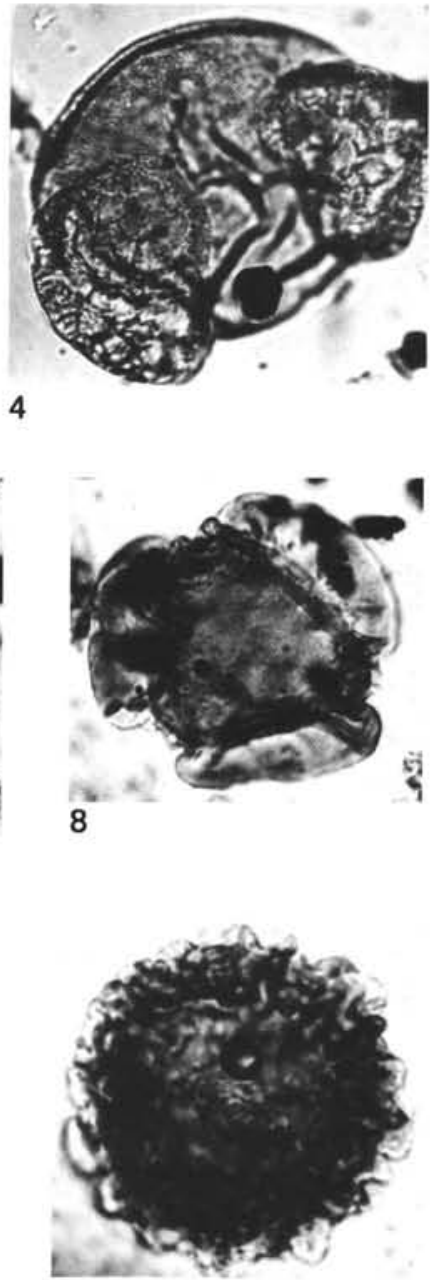$$
8
$$

12

Plate 11. (All specimens magnified $\times 600$.) 1-6. Disaccites (1) Sample 511-57-5, 33-35 cm $(2,6)$ Sample 511-70-4, 22-24 cm (3) Sample 511-57-4, 33-35 cm (5) Sample 511-69-2, 42-44 cm. 7. Callialasporites dampieri (Balme) Sukh Dev, Sample 511-70-5, 22-24 cm. 8-9. Callialasporites trilobatus (Balme) Sukh Dev (8) Sample 511-63-1, 130-134 cm (9) Sample 511-69-2, 42-44 cm. 10-11. Callialasporites turbatus (Balme) Schulz (10) Sample 511-69-2, 42-44 cm (11) Sample 511-70-1, 22-24 cm. 12. Callialasporites segmentatus (Balme) Srivastava, Sample 511-70-1, 22-24 $\mathrm{cm}$. 13. Exesipollenites sp., Sample 511-70-3, 22-24 cm. 14-15. Peromonolites sp. (14) Sample 511-64-4, 79-83 cm (15) Sample 511-67-2, $82-84 \mathrm{~cm}$. 


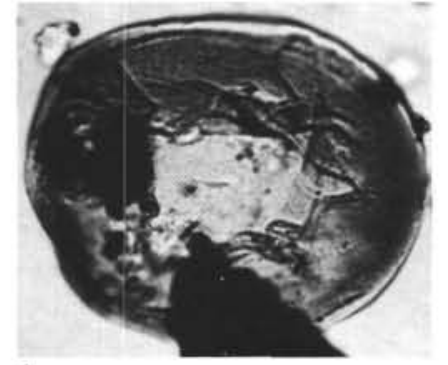

1

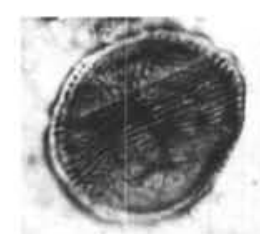

5
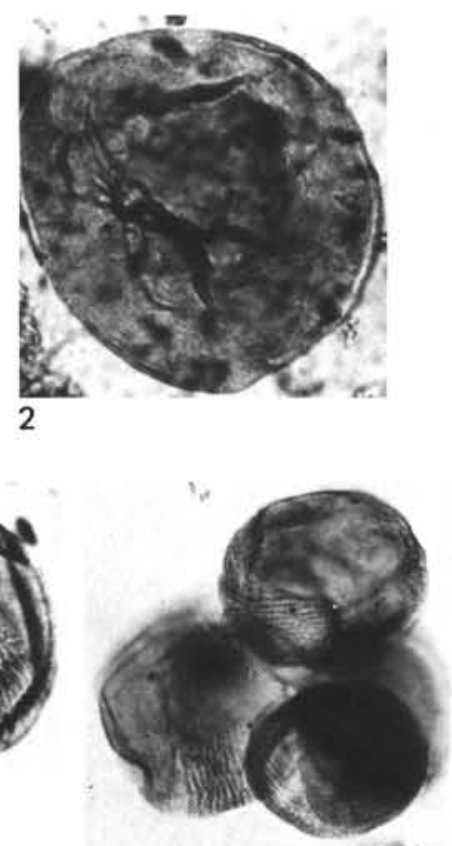

7
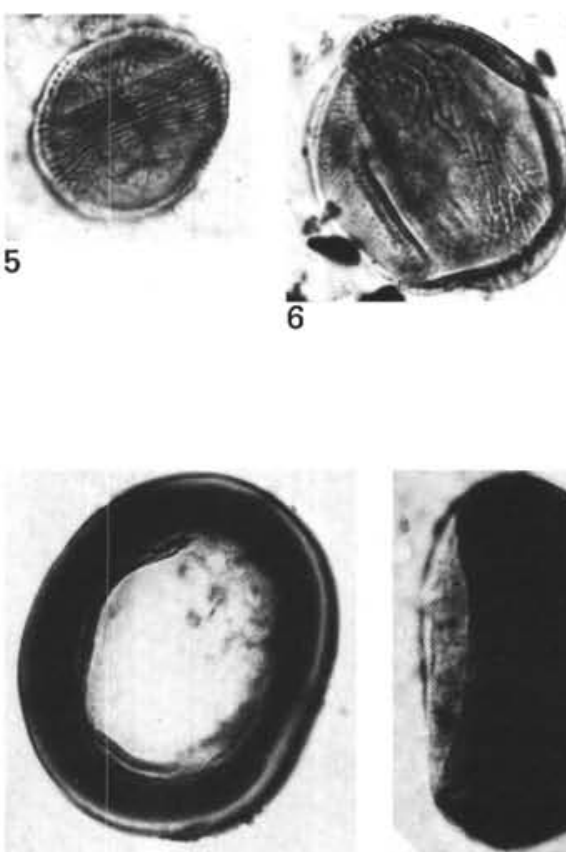

10

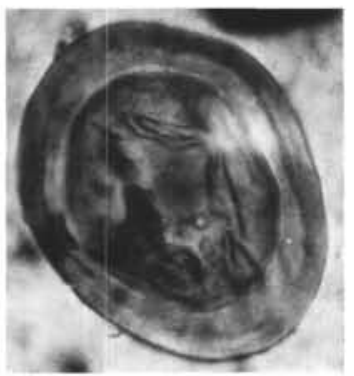

15

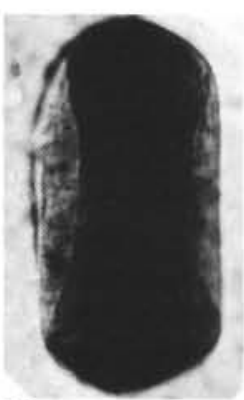

11

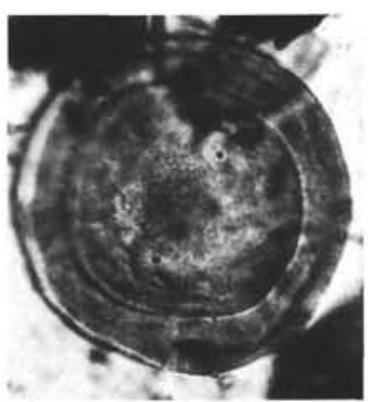

12

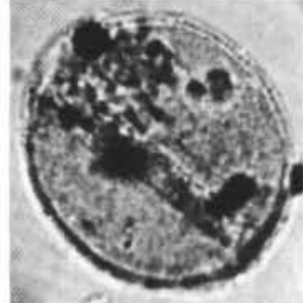

16

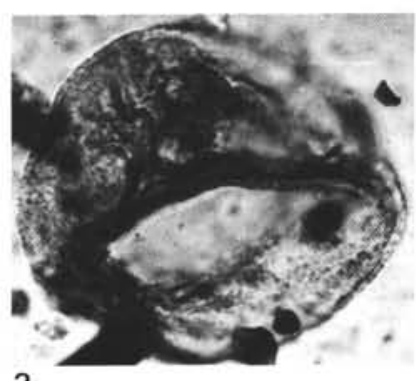

3

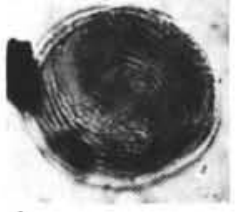

4

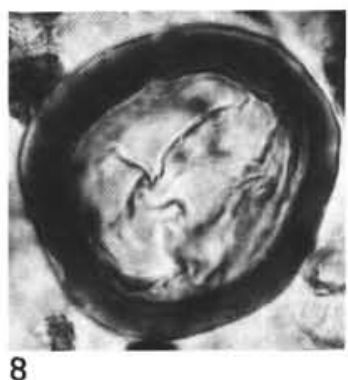

8

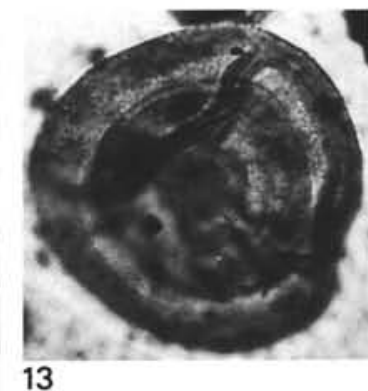

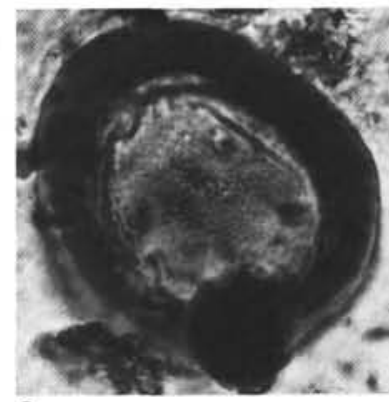

9

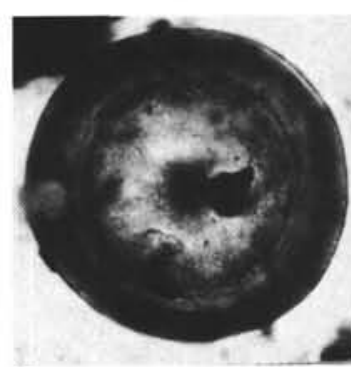

14

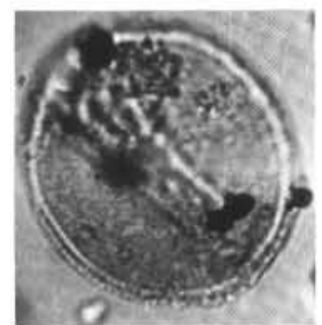

17

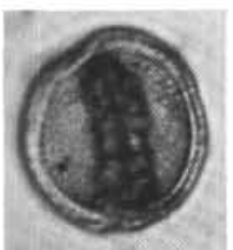

18

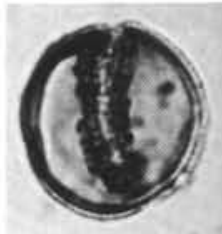

19

Plate 12. (Figs. 1-15 ×600; Figs. 16-19 × 1000.) 1. Inaperturopollenites limbatus Balme, Sample 511-57-6, 33-35 cm. 2. Inaperturopollenites sp., Sample 511-70-3, 22-24 cm. 3. Araucariacites australis (Cookson) Couper, Sample 511-69-2, 42-44 cm. 4-7. Classopollis spp. (4-6) Sample 511-70-5, 22-24 cm (7) Sample 511-69-2, 42-44 cm. 8-11. Cyclusphaera psilata Volkheimer and Sepulveda (8-9) Sample 511-62-1, 38-42 cm (10) Sample 511-57-2, 33-35 cm (11) Sample 511-56-5, 58-60 cm. 12-15. Cyclusphaera sp. A (12-13) Sample 511-57-3, 33-35 cm (14) Sample 511-57-1, 33-35 cm (15) Sample 511-58-2, 142-144 cm. 16-17. Clavatipollenites rotundus Kemp, Sample 511-57-6, 33-35 cm. 18-19. Clavatipollenites incisus Chlonova, Sample 511-58-2, 142-144 cm. 


\section{Z. KOTOVA}

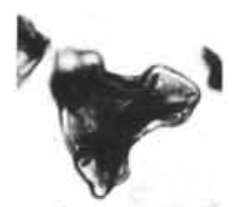

1
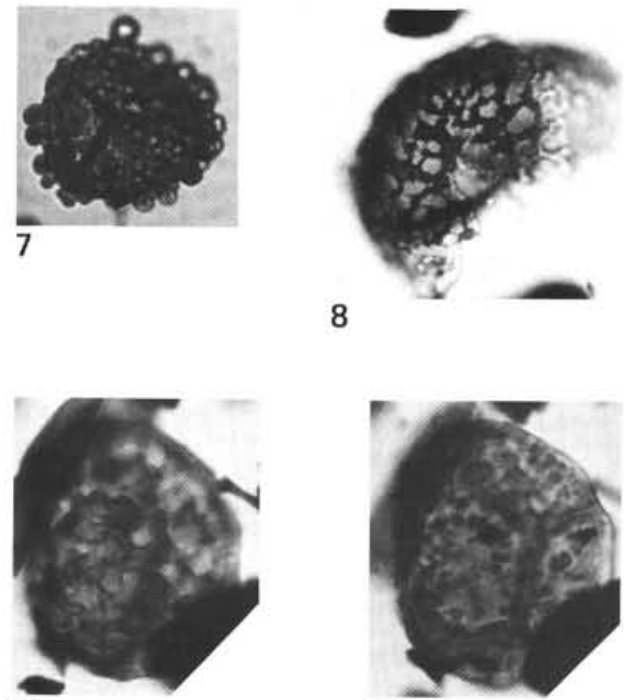

13

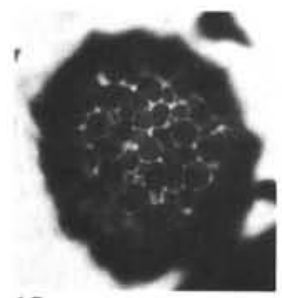

18
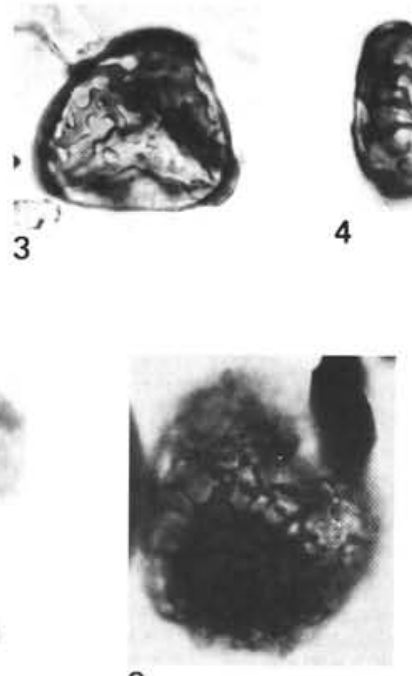

9

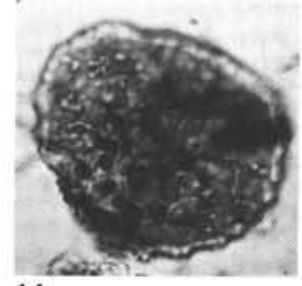

14

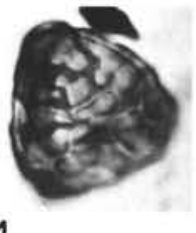

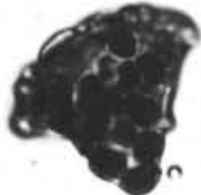

5

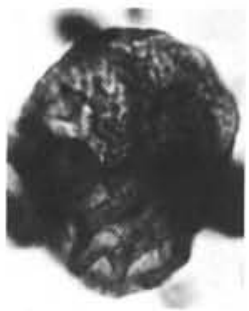

10
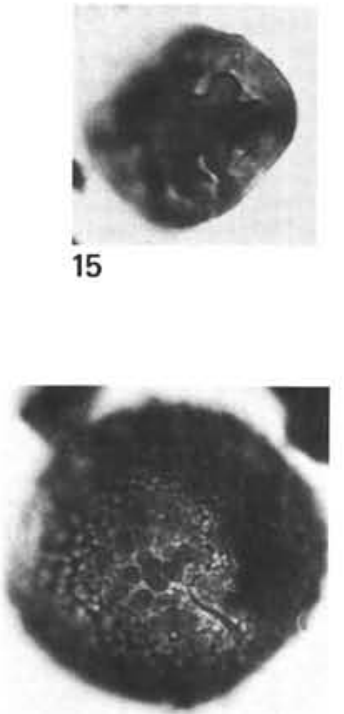

20

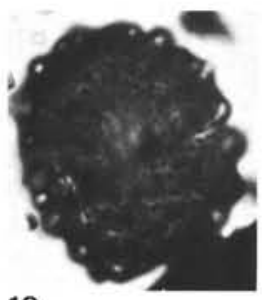

19
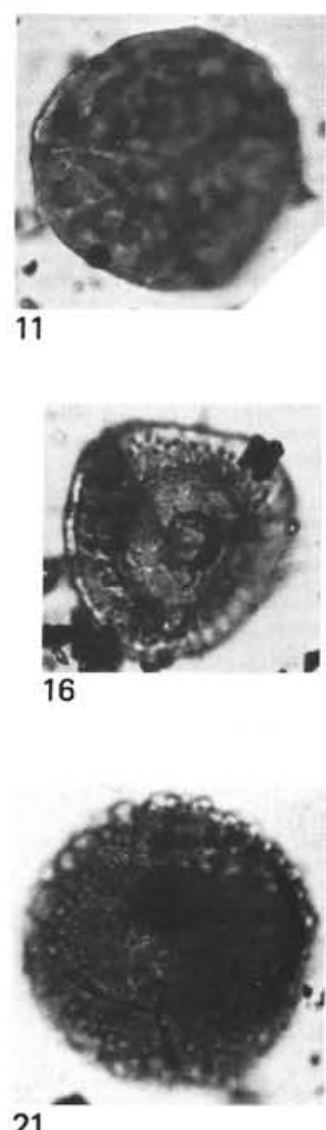

21

Plate 13. (All specimens magnified $\times 600$.) 1-2. Auritulinasporites intrastriatus Nilsson (1) Sample 330-14-4, 70-74 cm (2) Sample 330-14-2, 18-21 $\mathrm{cm}$. 3-4. Polypodiaceoisporites neuquenensis Volkheimer, Sample 330-14-4, 70-74 cm. 5. Trilites sp. 2, Sample 330-13-3, 112-116 cm. 6-7. Clavatisporites sp., Sample 330-13-3, 112-116 cm. 8-9. Retitriletes sp., Sample 330-13-3, 112-116 cm. 10-13. Interulobites sp. A (10) Sample $330-14-4,70 \mathrm{~cm}$ (11-13) Sample 330-12-5, 72-76 cm. 14. Interulobites algoensis Scott, Sample 330-11-5, 120-124 cm. 15. Interulobites sinuosus Scott, Sample 330-6-5, 90-94 cm. 16. Coronatispora perforata Dettmann, Sample 330-11-6, 90-93 cm. 17. Crybelosporites aff. berberioides Burger, Sample 330-8-4, 114-117 cm. 18-21. Leptolepidites sp. 1 (18-20) Sample 330-13-4, 116-120 cm (21) Sample 330-13-2, $69-73 \mathrm{~cm}$. 


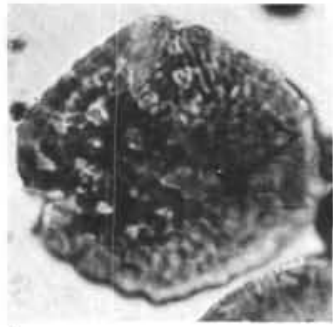

1

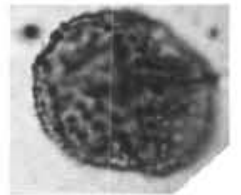

6

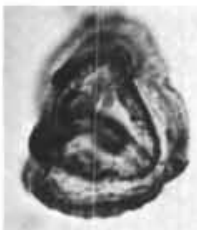

11
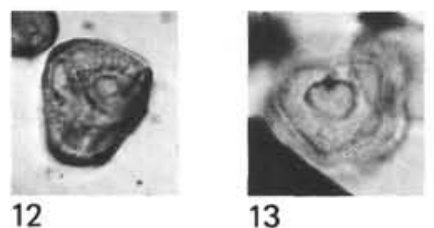

13

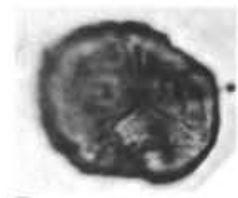

7

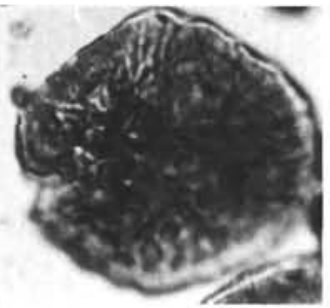

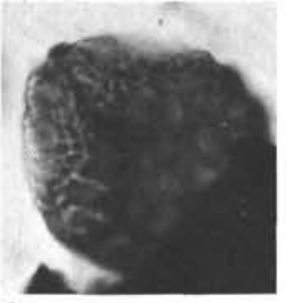

3

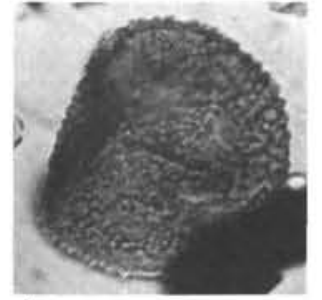

4
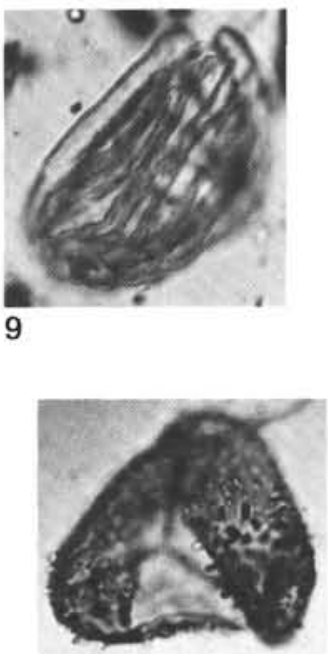

15

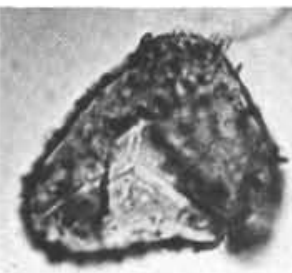

14

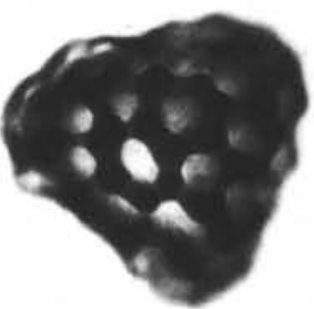

20

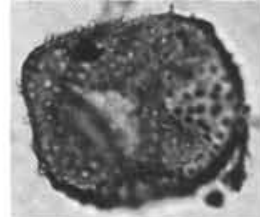

5

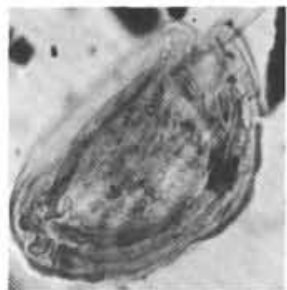

10

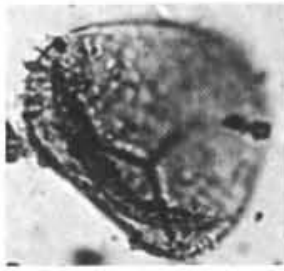

16

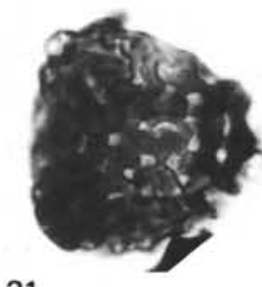

21

19

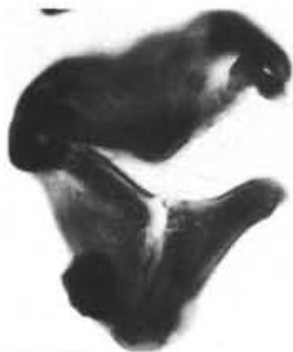

Plate 14. (All specimens magnified $\times 600$.) $\quad 1-3$. Verrucosisporites $\mathrm{sp}$. E (1-2) Sample 330-13-2, 69-73 cm (3) Sample 330-12-6, 111-115 cm. 4. Verrucosisporites sp. 1, Sample 330-12-3, 70-74 cm. 5-7. Neoraistrickia suratensis McKellar (5) Sample 330-13-4, 116-120 cm (6-7) Sample 330-13-2, 69-73 cm. 8. Contignisporites cooksonii (Balme) Dettmann, Sample 330-13-3, 112-116 cm. 9-10. Contignisporites sp., Sample 330-12-3, 70-74 cm. 11. Polycingulatisporites crenulatus Playford and Dettmann, Sample 330-7-3, 82-86 cm. 12. Polycingulatisporites striatus Filatoff, Sample 330-14-3, 92-96 cm. 13. Polycingulatisporites sp., Sample 330-12-6, 111-115 cm. 14-17. Conbaculatisporites sp. (14-15) Sample 330-14-2, 18-21 cm (16-17) Sample 330-13-2, 69-73 cm. 18-20. Ischyosporites crateris Balme (18-19) Sample 330-14-3, 92-96 cm (20) Sample 330-13-3, 112-116 cm. 21. Ischyosporites sp., Sample 330-13-2, 69-73 cm. 


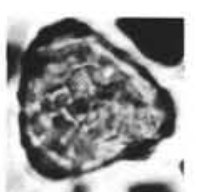

1

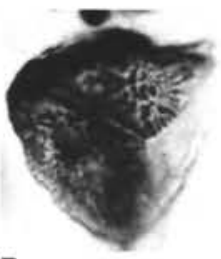

7

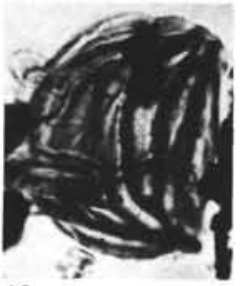

12
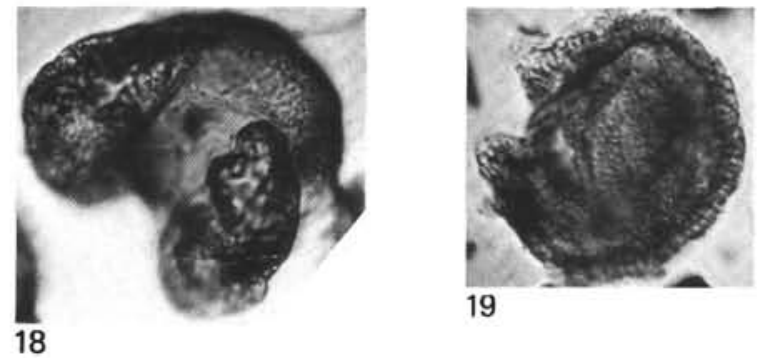

19

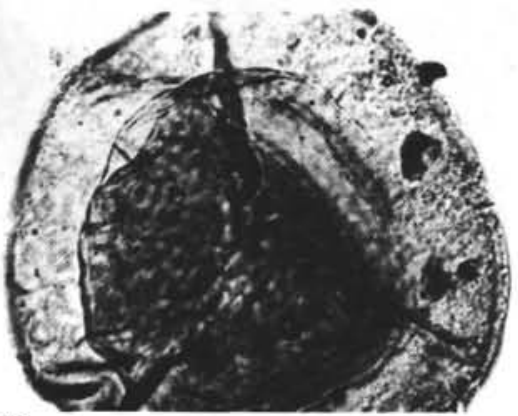

22
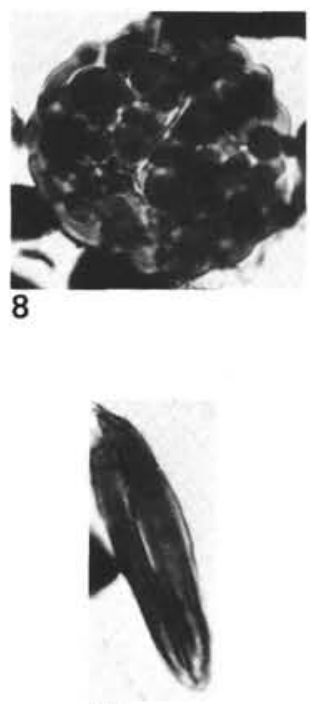

13

23

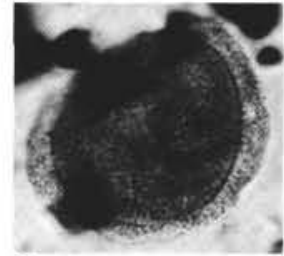

3

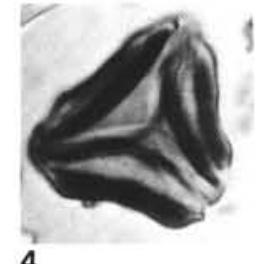

4

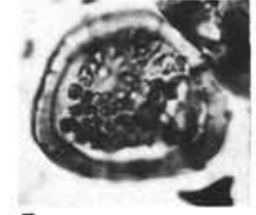

5

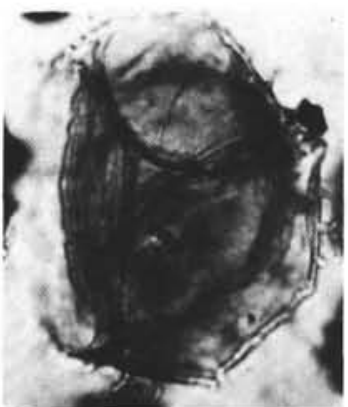

10

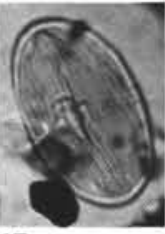

15

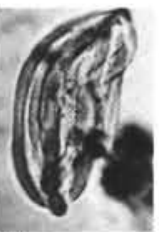

14

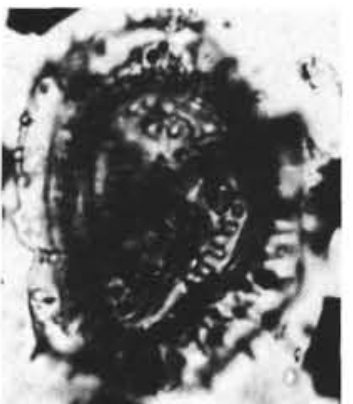

9

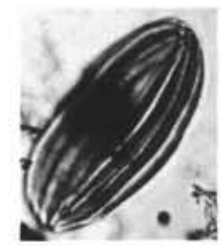

16

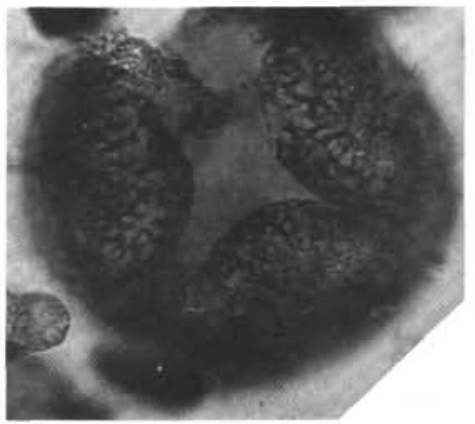

20

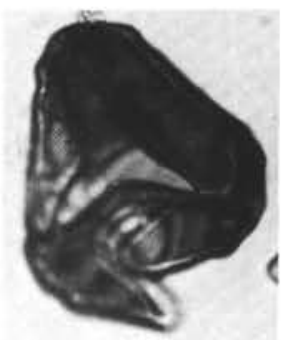

11

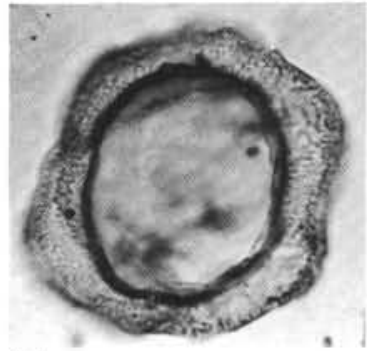

17

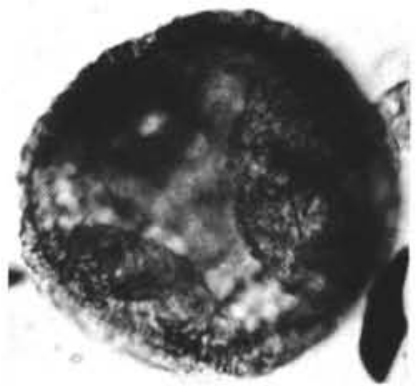

21

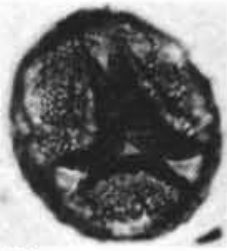

Plate 15. (All specimens magnified $\times 600$.) 1. Ischiosporites volkheimeri Filatoff, Sample 330-11-5, 120-124 cm. 2. Laevigatosporites sp., Sample 330-13-3, 112-116 cm. 3. Dictyotosporites complex Cookson and Dettmann, Sample 330-14-4, 70-74 cm. 4. Gleicheniidites sp., Sample 330-14-2, 18-21 cm. 5. Antulsporites saevus (Balme) Archangelsky and Gamerro, Sample 330-7-5, 90-94 cm. 6. Kuylisporites lunaris Cookson and Dettmann, Sample 330-7-5, 90-94 cm. 7. Nevesisporites sp., Sample 330-6-5, 90-94 cm. 8. Leptolepidites macroverrucosus Schulz, Sample 330-11-3, 83-87 cm. 9,10. Cyclocrystella sp., Sample 330-8-4, 114-117 cm. 11. Trilobosporites antiquus Reiser and Williams, Sample 330-13-3, 112-116 cm. 12. Cicatricosisporites sp., Sample 330-6-1, 43-47 cm. 13. Ephedripites sp. 2, Sample 330-14-2, 18-21 cm. 14. Ephedripites sp. 1, Sample 330-6-1, 43-47 cm. 15. Ephedripites sp. 3, Sample 330-6-3, 102-105 cm. 16. Ephedripites sp., Sample 330-9-2, 92-95 cm. 17. Monosaccites sp. 1, Sample 330-13-2, 69-73 cm. 18. Indusispora sp., Sample 330-14-2, 18-21 cm. 19. Podosporites sp., Sample 330-7-3, 82-86 cm. 20-21. Podosporites sp. 1 (20) Sample 330-12-3, 70-74 cm (21) Sample 330-13-4, 116-120 cm. 22. Callialasporites sp., Sample 330-14-4, 70-74 cm. 23. Trisaccites sp., Sample 330-13-3, 112-116 cm. 